\title{
Water uptake is independent of the inferred composition of secondary aerosols derived from multiple biogenic VOCs
}

\author{
M. R. Alfarra ${ }^{1,2}$, N. Good ${ }^{1, *}$, K. P. Wyche ${ }^{3}$, J. F. Hamilton ${ }^{4}$, P. S. Monks ${ }^{3}$, A. C. Lewis ${ }^{5}$, and G. McFiggans ${ }^{1}$ \\ ${ }^{1}$ Centre for Atmospheric Science, School of Earth Atmospheric and Environmental Sciences, \\ University of Manchester, Manchester, UK \\ ${ }^{2}$ National Centre for Atmospheric Science (NCAS), School of Earth Atmospheric and Environmental Sciences, \\ University of Manchester, Manchester, UK \\ ${ }^{3}$ Atmospheric Chemistry Group, Department of Chemistry, University of Leicester, Leicester, UK \\ ${ }^{4}$ Department of Chemistry, University of York, York, UK \\ ${ }^{5}$ National Centre for Atmospheric Science, University of York, York, UK \\ *now at: Department of Environmental \& Radiological Health Sciences, Colorado State University, \\ Fort Collins, Colorado, USA
}

Correspondence to: M. R. Alfarra (rami.alfarra@manchester.ac.uk)

Received: 25 March 2013 - Published in Atmos. Chem. Phys. Discuss.: 24 April 2013

Revised: 24 October 2013 - Accepted: 5 November 2013 - Published: 4 December 2013

\begin{abstract}
We demonstrate that the water uptake properties derived from sub- and super-saturated measurements of chamber-generated biogenic secondary organic aerosol (SOA) particles are independent of their degree of oxidation, determined using both online and offline methods. SOA particles are formed from the photooxidation of five structurally different biogenic VOCs, representing a broad range of emitted species and their corresponding range of chemical reactivity: $\alpha$-pinene, $\beta$-caryophyllene, limonene, myrcene and linalool. The fractional contribution of mass fragment 44 to the total organic signal $\left(f_{44}\right)$ is used to characterise the extent of oxidation of the formed SOA as measured online by an aerosol mass spectrometer. Results illustrate that the values of $f_{44}$ are dependent on the precursor, the extent of photochemical ageing as well as on the initial experimental conditions. SOA generated from a single biogenic precursor should therefore not be used as a general proxy for biogenic SOA. Similarly, the generated SOA particles exhibit a range of hygroscopic properties, depending on the precursor, its initial mixing ratio and photochemical ageing. The activation behaviour of the formed SOA particles show no temporal trends with photochemical ageing. The average $\kappa$ values derived from the HTDMA and $\mathrm{CCNc}$ are generally found to cover the same range for each precursor under two different initial mixing ratio conditions. A positive
\end{abstract}

correlation is observed between the hygroscopicity of particles of a single size and $f_{44}$ for $\alpha$-pinene, $\beta$-caryophyllene, linalool and myrcene, but not for limonene SOA. The investigation of the generality of this relationship reveals that $\alpha$ pinene, limonene, linalool and myrcene are all able to generate particles with similar hygroscopicity $\left(\kappa_{\mathrm{HTDMA}} \sim 0.1\right) \mathrm{de}-$ spite $f_{44}$ exhibiting a relatively wide range of values $(\sim 4$ to $11 \%)$. Similarly, $\kappa_{\mathrm{CCN}}$ is found to be independent of $f_{44}$. The same findings are also true when sub- and super-saturated water uptake properties of SOA are compared to the averaged carbon oxidation state $\left(\overline{\mathrm{OS}_{\mathrm{C}}}\right)$ determined using an offline method. These findings do not necessarily suggest that water uptake and chemical composition are not related. Instead, they suggest that either $f_{44}$ and $\mathrm{OS}_{\mathrm{C}}$ do not represent the main dominant composition-related factors controlling water uptake of SOA particles, or they may emphasise the possible impact of semi-volatile compounds on limiting the ability of current state-of-the-art techniques to determine the chemical composition and water uptake properties of aerosol particles. 


\section{Introduction}

Atmospheric oxidation of volatile, semi-volatile and intermediate volatility organic compounds (VOCs, SVOCs, and IVOCs) produces lower volatility species that partition into the condensed phase and form secondary organic aerosol (SOA) (Seinfeld and Pankow, 2003; Hallquist et al., 2009; Robinson et al., 2007; Donahue et al., 2011). Biogenic hydrocarbons are a dominant contributor to the global VOC budget and are known for their high reactivity towards the main atmospheric oxidants (e.g. hydroxyl radical, nitrate radical and ozone), which makes them major contributors to the total atmospheric burden of SOA (Atkinson and Arey, 2003; Kanakidou et al., 2005; Hallquist et al., 2009; Goldstein and Galbally, 2007). Understanding the formation and properties of biogenic SOA is a necessary step towards assessing the influence of atmospheric aerosols on major areas of concern such as climate change and human health.

Over the last three decades, a large body of literature has been established focusing on the formation of SOA from biogenic and anthropogenic hydrocarbons (Hallquist et al., 2009; Kroll and Seinfeld, 2008; Kanakidou et al., 2005). In situ investigation of key physical and chemical processes during biogenic SOA formation in the atmosphere is complicated by the vast number of species involved and their generally low mixing ratios. Reaction chambers have therefore often been used to study these processes. The conventional reaction chamber (also referred to as smog chamber) is a large confined volume used as a batch reactor in which mixtures of atmospherically relevant trace gases (e.g. hydrocarbons, nitrogen oxides, sulphur dioxide) are oxidised in purified air under dark conditions or with the use of sunlight or artificial illumination. Such experiments can be useful in understanding the chemical and physical parameters that control the formation and transformation of secondary organic aerosols, their properties and atmospheric impacts. Hallquist et al. (2009) have listed the characteristics of selected smog chambers and reviewed recent developments in smog chamber SOA studies.

Much of the early effort has focused on the investigation of gas-particle partitioning of VOC oxidation products through quantification of the aerosol formation potential (aerosol yield) of small aromatic and biogenic hydrocarbons (Pandis et al., 1992; Odum et al., 1996; Griffin et al., 1999). Other studies have attempted to identify the molecular composition of the oxidation products of anthropogenic and biogenic precursors, mainly aromatic and monoterpene compounds, and have offered detailed reaction mechanisms for the formation of various chemical species (Forstner et al., 1997; Glasius et al., 2000; Jang and Kamens, 2001; Jaoui and Kamens, 2003; Kleindienst et al., 2004). Over the last decade or so, a number of studies have suggested that the first reported SOA yield values for some of the most commonly studied VOCs were too low. Revised, higher SOA yield values have been reported for a number of SOA systems, including $\alpha$-pinene
(Ng et al., 2006; Chan et al., 2007; Shilling et al., 2008), isoprene (Chan et al., 2007; Kroll et al., 2006), toluene (Hildebrandt et al., 2009) and $m$-xylene (Ng et al., 2007). A large fraction of the studies reported in the literature have focused on the characterisation of the chemical and/or microphysical properties of SOA systems produced from the oxidation of an individual VOC precursor. Examples of these studies include the effect of $\mathrm{NO}_{\mathrm{x}}$ concentration (Presto et al., 2005a) and UV radiation (Presto et al., 2005b) on $\alpha$-pinene SOA formation; the formation of SOA from isoprene oxidation (Carlton et al., 2009; Kroll et al., 2006; Dommen et al., 2006, 2009); and the contribution of second generation oxidation products to $\beta$-caryophyllene SOA formation (Li et al., 2011). Other studies have investigated the SOA formation for a range of VOC compounds under comparable experimental studies. For example, Lee et al. (2006a) reported SOA yields and gas-phase oxidation products from the ozonolysis of 10 terpene compounds. In a successive study, the same researchers reported SOA yield values and detailed characterisation of gas-phase oxidation products from a series of photooxidation experiments conducted using 16 terpene compounds (Lee et al., 2006b). A more detailed analysis of the contribution of firstand second-generation oxidation products to SOA production and formation mechanisms - in the latter set of experiments - were presented by $\mathrm{Ng}$ et al. (2006). More recently, Chhabra et al. (2011) compared spectral and elemental ratio data from the high-resolution Aerodyne aerosol mass spectrometer to offline species identification analysis in order to investigate changes in functional and elemental composition during SOA formation and transformation using a wide range of VOC precursors.

Simultaneously, several efforts have been made over the last decade or so to characterise the cloud condensation nuclei (CCN) activity and hygroscopic properties of SOA particles produced during the ozonolysis or photooxidation of biogenic and anthropogenic VOCs. VanReken et al. (2005) investigated the potential for 5 biogenic SOA types, produced in dark ozonolysis experiments, to act as CCN. Varutbangkul et al. (2006) studied the sub-saturated water uptake properties of SOA formed by photooxidation of monoterpenes, sesquiterpenes and oxygenated terpenes. The influence of the initial precursor mixing ratio on the composition and/or hygroscopic properties have been reported for SOA produced from oxidation of $\alpha$-pinene (Duplissy et al., 2008; Shilling et al., 2009; King et al., 2009) and $\beta$-caryophyllene (Alfarra et al., 2012). The influence of particle volatility on composition, hygroscopic properties and $\mathrm{CCN}$ activity have been studied for a number of SOA systems, including $\alpha$-pinene (Meyer et al., 2009; Tritscher et al., 2011) and $\beta$-caryophyllene (AsaAwuku et al., 2009; Tang et al., 2012; Frosch et al., 2013).

Attempts to relate the chemical composition of SOA particles to their hygroscopic and $\mathrm{CCN}$ properties have recently been made. Massoli et al. (2010) investigated the relationship between the oxidation level $(\mathrm{O}: \mathrm{C}$ ratio $)$ and the hygroscopic and $\mathrm{CCN}$ properties of laboratory SOA particles generated 
via $\mathrm{OH}$ radical oxidation of $\alpha$-pinene, trimethylbenze (TMB) and $m$-xylene in separate flow reactor experiments. The study found that the hygroscopic properties at $90 \%$ relative humidity $(\mathrm{RH})$ increased linearly with $\mathrm{O}: \mathrm{C}$ value for the studied systems. Similarly, an increase in the CCN activity was reported as a function of $\mathrm{O}: \mathrm{C}$. However, the later relationship was reported to be system-dependent and not a linear one. A semi-empirical parameterisation of hygroscopic growth at $90 \% \mathrm{RH}$ and $\mathrm{O}: \mathrm{C}$ was proposed, whereas a general parameterisation for the $\mathrm{CCN}$ activity vs. $\mathrm{O}: \mathrm{C}$ relationship was reported to be difficult to establish. Similarly, Frosch et al. (2011) found that the level of oxygenation of $\alpha$-pinene SOA increased with decreasing precursor mixing ratio and with chemical ageing, whereas $\mathrm{CCN}$ activity was largely independent of O:C ratio. Duplissy et al. (2011) determined a simple empirical linear relation between sub-saturated hygroscopic growth and the level of oxygenation of SOA produced from the photooxidation of $\alpha$-pinene, isoprene and TMB. The same analysis was also performed on ambient organic aerosol data at two contrasting locations, where similar findings were reported.

In this study, we extend the investigations of SOA composition and properties using a carefully selected set of 5 structurally different biogenic VOCs covering a range of chemical reactivity. Specifically, we will (i) illustrate the variability in the chemical composition and sub- and super-saturated water uptake properties of SOA generated from the photooxidation of the selected VOCs under controlled and comparable conditions in a reaction chamber; and (ii) investigate and discuss the relationship between the sub- and super-saturated water uptake of the generated SOA particles and their chemical composition determined using on- and offline analytical methods.

\section{Experimental}

\subsection{Chamber description}

Experiments were conducted in the photochemical aerosol reaction chamber at the University of Manchester (Alfarra et al., 2012; Hamilton et al., 2011). The chamber is run as a batch reactor where the composition of the gaseous precursors, oxidising environment, relative humidity and temperature are controlled. It comprises an $18 \mathrm{~m}^{3}(3 \mathrm{~m}$ $(\mathrm{H}) \times 3 \mathrm{~m}(\mathrm{~L}) \times 2 \mathrm{~m}(\mathrm{~W}))$ FEP Teflon bag mounted on three horizontal rectangular aluminium frames. The central rigid frame is fixed, with the upper and lower frames free to move vertically, allowing the bag to expand and collapse as sample air is introduced and extracted. Air is supplied to the chamber by a blower at a flow of $3 \mathrm{~m}^{3} \mathrm{~min}^{-1}$. The air is dried and filtered for gaseous impurities and particles using a series of Purafil (Purafil Inc., USA), charcoal and HEPA filters (Donaldson Filtration, USA) prior to humidification with ultrapure deionised water. Halogen bulbs and a $6 \mathrm{~kW}$ Xenon arc lamp are mounted on the inside of the enclosure housing the bag, which is coated with reflective "space blanket", serving to maximise the irradiance in the bag and to ensure even illumination. The combination of illumination has been tuned and evaluated to mimic the atmospheric actinic spectrum over the wavelength range $290-800 \mathrm{~nm}$, and has a maximum total actinic flux of $0.7 \times 10^{18}$ (photon $\mathrm{s}^{-1} \mathrm{~m}^{-2} \mathrm{~nm}^{-1}$ ) over the region $460-500 \mathrm{~nm}$. The calculated $j \mathrm{O}\left({ }^{1} \mathrm{D}\right)$ value during the reported experiments was $3.6 \times 10^{-5} \mathrm{~s}^{-1}$ (290$340 \mathrm{~nm})$ and $j \mathrm{NO}_{2}$ was $6 \times 10^{-4} \mathrm{~s}^{-1}(290-422 \mathrm{~nm})$.

Precursor VOCs are introduced into the bag via injection into a heated glass bulb, which is continually flushed with a flow of filtered, high purity nitrogen (ECD grade, $99.997 \%$ ). The desired concentration of $\mathrm{NO}_{\mathrm{x}}$ is controlled by injection of $\mathrm{NO}_{2}$ from a cylinder into the charge line. Relative humidity $(\mathrm{RH})$ and temperature are measured at the centre and the edge of the chamber (by dewpoint hygrometer and a crosscalibrated thermocouple and resistance probe), and are controlled by diverting air through the inlet humidification circuit when filling the bag and by controlling the set point of the air conditioning, which feeds the airspace between the bag and its enclosure. Cycling between experiments is facilitated by automated computer control and monitoring of key chamber conditions. Pre- and post-experiment cleaning processes consist of a series of fill/flush cycles with $3 \mathrm{~m}^{3} \mathrm{~min}^{-1}$ flow of clean air, enabled by control of electro-pneumatic valves followed, post-experiment, by an overnight soaking at high mixing ratios of ozone (2-2.5 ppmV, supplied by a high capacity ozone generator). Each cycle takes approximately 12 min and cleaning is normally achieved after approximately 6 cycles. A particle mass background value of $0.1-0.2 \mu \mathrm{g} \mathrm{m}^{-3}$ is attained following these cleaning procedures.

\subsection{Experimental conditions and methodology}

SOA particles were formed in experiments involving the photooxidation of individual precursors in the presence of $\mathrm{NO}_{\mathrm{x}}$ and in the absence of seed particles. Precursor VOCs limonene (R-(+)-Limonene, Fluka, $\geq 99.0 \%)$, myrcene $(\geq 95.0 \%$, Fluka), linalool ((-)-Linalool, $\geq 98.5 \%$, Fluka), $\alpha$-pinene (98\%, Aldich) and $\beta$-caryophyllene (Aldrich, purity not specified) were investigated, each at two different nominal initial mixing ratios of 50 and $250 \mathrm{ppbV}$, in order to study the effect of initial precursor mixing ratio on SOA properties and composition. VOC measurements (described in Sect. 2.3) were made during some of the experiments and the measured initial precursor mixing ratios during those experiments are reported in Table 1. Where not measured, the nominal initial precursor mixing ratios were estimated from the amount injected into the heated bulb and introduced into the chamber via the high flow rate inlet without accounting for losses. Experimental protocol consisted of the addition of required amounts of the precursor, $\mathrm{NO}_{\mathrm{x}}$ and water vapour during the final filling cycle of the chamber; ensuring that 
all ingredients were well-mixed by the end of the cycle as a result of the high flow rate at which the clean air was introduced. Air conditioning was switched on shortly before the arc lamp and halogen bulbs were illuminated, marking the start of the photochemistry and the experiment $\left(t_{0}\right)$. An overview of the conditions used in each experiment is given in Table 1.

\subsection{Instrumentation}

Real-time broad chemical characterisation of the SOA was made using a compact Time-of-Flight Aerosol Mass Spectrometer (cToF-AMS, Aerodyne Research Inc., USA). A detailed description of the instrument, its operation and calibrations can be found elsewhere (Drewnick et al., 2005; Canagaratna et al., 2007). The instrument was operated in the standard configuration, taking both mass spectrum (MS) and particle time-of-flight (PToF) data and was calibrated for ionisation efficiency using $350 \mathrm{~nm}$ monodisperse ammonium nitrate particles. The vaporiser was set at approximately $600^{\circ} \mathrm{C}$ and data were collected at a time resolution of $2 \mathrm{~min}$. A collection efficiency value of unity was applied to these data, based on evidence from a previous chamber study (Alfarra et al., 2006).

A hygroscopicity tandem differential mobility analyser (HTDMA) was used to measure online size resolved water uptake at $90 \% \mathrm{RH}$. A technical description of the instrument was provided in Good et al. (2010a) and Cubison et al. (2006). Briefly, the HTDMA dries the aerosol sample to $<10 \%$ RH using a Nafion ${ }^{\circledR}$ drier (Perma Pure, MD-110-12, Toms River, NJ, USA). A DMA (BMI, Haywood, CA, USA) selects particles of a single mobility. In this work, diameters chosen were larger than the mode of the number size distribution, thus avoiding the sampling of a significant fraction of multi-charged particles. The sample is then humidified to $90 \%$ RH using a humidifier, comprising a Gore-Tex ${ }^{\circledR}$ tube running through a controlled humid counter-flow of air. The humidified size selected sample is then passed through a residence coil for $15 \mathrm{~s}$. A second DMA (BMI, Haywood, CA, USA) and water-based condensation particle counter (WCPC 3782, TSI Inc., USA) are then used to measure the size distribution of the humidified sample. The operating procedure of the HTDMA was validated by sampling ammonium sulphate and sodium chloride test aerosols, following Good et al. (2010a), and inverted using TDMAInv (Gysel et al., 2009). The data from the HTDMA are reported in terms of the hygroscopic growth factor $\left(\mathrm{GF}_{D 0_{\mathrm{RH}}}\right)$, the wet particle diameter at a given $\mathrm{RH}$ divided by the particle's dry diameter $\left(D_{0}\right)$.

The cloud condensation nuclei (CCN) activity of the particles was characterised using a continuous flow $\mathrm{CCN}$ counter (Droplet Measurement Technologies, USA) combined with a Vienna style DMA (Winklmayr et al., 1991) and a condensation particle counter (CPC 3010, TSI Inc., USA). The DMA was used to generate monodisperse aerosol in the size range between $20 \mathrm{~nm}$ and $500 \mathrm{~nm}$ dry diameter. These particles were directed in parallel to the CPC and CCN counters. The inlet flow in the CCN counter was $0.5 \mathrm{lpm}$ and it was operated at different supersaturations in the range between $0.07 \%$ and $1 \%$ for each particle size. The calibration and quality assurance procedures carried out for this set-up is described in Good et al. (2010a). Using the instrumental setup described above $\mathrm{CCN}$ and $\mathrm{CN}$ number size distributions were measured at a temperature difference $(\Delta T)$ equivalent to supersaturations between $0.07 \%$ and $1.0 \%$. The $\mathrm{CCN}$ and $\mathrm{CN}$ number size distributions were then inverted to account for charging efficiency and multiple charging (Good et al., 2010a). The inverted number size distributions were then used to calculate the activated fraction $(\mathrm{CCN} / \mathrm{CN})$ as a function of dry size. Sigmoidal functions were then fitted to the activation curve, from which the dry diameter at which $50 \%$ of the particles were activated was calculated. Given that the aerosol was internally mixed, the diameter at which $50 \%$ of the particles activate $\left(D_{50}\right)$ was reasonably interpreted to be the dry diameter at which the particles are activated as CCN at the set-point supersaturation (Good et al., 2010b). $\kappa$ values (Petters and Kreidenweis, 2007) are then iteratively derived from the $\mathrm{CCN}$ derived critical supersaturation and dry diameter.

Total particle number concentrations were measured using a water-based condensation particle counter with a minimum particle size cut-off of $2.5 \mathrm{~nm}$ (WCPC 3786, TSI Inc., USA). $\mathrm{NO}$ and $\mathrm{NO}_{2}$ mixing ratios were measured using a chemiluminescence gas analyser (Model 42i, Thermo Scientific, MA, USA). Ozone was measured using a UV photometric gas detector (Model 49C, Thermo Scientific, MA, USA).

The gas-phase organic compounds within the chamber were measured using Chemical Ionisation Reaction Time-ofFlight Mass Spectrometry (CIR-TOF-MS). This technique has been previously described (Wyche et al., 2007; Jenkin et al., 2012). The CIR-TOF-MS instrument comprises a bespoke, temperature controlled $\left(40^{\circ} \mathrm{C} \pm 1{ }^{\circ} \mathrm{C}\right)$ radioactive $\left({ }^{241} \mathrm{Am}\right)$ ion source/drift tube assembly, coupled via a system of ion transfer optics to an orthogonal time-of-flight mass spectrometer (Kore Technology, UK). In this instance, hydrated hydronium ions $\left(\mathrm{H}_{3} \mathrm{O}^{+} \cdot\left(\mathrm{H}_{2} \mathrm{O}\right)\right)$, generated from a humidified $\mathrm{N}_{2}$ carrier gas (purity $=99.9999 \%$ ), were employed as the primary chemical ionisation reagent. Under the conditions of the applied drift tube parameters, ion-molecule reaction between the analyte VOC/OVOC, M, and the hydrated hydronium ion would yield a protonated VOC/OVOC product ion $\left(\mathrm{MH}^{+}\right)$for mass spectrometric analysis, providing the analyte has a proton affinity greater than that of the water dimer $\left(808 \mathrm{~kJ} \mathrm{~mol}^{-1}\right)$. Depending on the energies involved and chemical structure of the VOC/OVOC analyte, the $\mathrm{MH}^{+}$product may undergo fragmentation to produce certain daughter ions. Mass spectrometric data were recorded by the CIR-TOF-MS over the range 1 and $300 \mathrm{Da}$ with a time resolution of $1 \mathrm{~min}$ and the signals of interest were converted 
Table 1. Overview of initial experimental conditions and SOA formation characteristics.

\begin{tabular}{|c|c|c|c|c|c|c|c|c|c|c|c|c|}
\hline $\begin{array}{c}\text { Exp } \\
\#\end{array}$ & Compound & $\begin{array}{r}{[\mathrm{VOC}]_{0}} \\
(\mathrm{ppbV})\end{array}$ & $\begin{array}{l}{\left[\mathrm{NO}_{\mathrm{X}}\right]_{0}} \\
(\mathrm{ppbV})^{\mathrm{b}}\end{array}$ & $\begin{array}{r}\text { Temp } \\
\left({ }^{\circ} \mathrm{C}\right)\end{array}$ & $\begin{array}{r}\text { Relative } \\
\text { Humidity } \\
(\mathrm{RH} \%)\end{array}$ & $\begin{array}{r}\text { Chemical } \\
\text { half-life } \\
(\min )^{\mathrm{a}}\end{array}$ & $\begin{array}{r}\text { Peak } \\
\text { Number } \\
\text { Conc. } \\
(\mathrm{p} / \mathrm{cc})\end{array}$ & $\begin{array}{r}\text { Peak } \\
\text { Number } \\
\text { Time } \\
(\text { min) }\end{array}$ & $\begin{array}{r}\text { Mass } \\
\text { Conc. } \\
\left(\mu \mathrm{g} \mathrm{m}^{-3}\right)^{\mathrm{d}}\end{array}$ & $\begin{array}{r}\Delta[\mathrm{VOC}] \\
(\mathrm{ppbV})\end{array}$ & $\begin{array}{c}\Delta[\mathrm{VOC}] \\
\left(\mu \mathrm{g} \mathrm{m}^{-3}\right)\end{array}$ & $\begin{array}{r}Y_{\text {SOA }} \\
(\%)\end{array}$ \\
\hline 1 & Myrcene & 44.2 & $31.3 \pm 0.8$ & $25.5 \pm 0.3$ & $54.2 \pm 0.9$ & 49.0 & $5.47 \mathrm{e}+4$ & 29 & 34.0 & 44.2 & 246.1 & 13.8 \\
\hline 2 & Myrcene & 254.8 & $137.2 \pm 0.2$ & $25.5 \pm 0.1$ & $52.3 \pm 0.4$ & 27.0 & $1.62 \mathrm{e}+5$ & 10 & 218.4 & 254.8 & 1418.8 & 15.4 \\
\hline 3 & Linalool & 77.0 & $29.1 \pm 0.7$ & $25.4 \pm 0.2$ & $48.0 \pm 0.4$ & 46.7 & $6.45 e+4$ & 46 & 17.4 & 77.0 & 485.5 & 3.6 \\
\hline 4 & Linalool & 176.6 & $121.9 \pm 1.2$ & $24.7 \pm 0.7$ & $52.5 \pm 1.5$ & 42.0 & $1.80 \mathrm{e}+5$ & 12 & 73.3 & 176.6 & 1113.5 & 6.6 \\
\hline 5 & $\alpha$-pinene $e^{g}$ & 45.0 & $34.2 \pm 0.3$ & $25.6 \pm 0.5$ & $71.4 \pm 1.2$ & 104.0 & $3.92 \mathrm{e}+4$ & 243 & 37.0 & 44.5 & 247.8 & 14.9 \\
\hline 6 & $\alpha$-pinene & $50^{\mathrm{f}}$ & $25^{\mathrm{f}}$ & $26.4 \pm 0.3$ & $51.4 \pm 1.4$ & - & $3.30 \mathrm{e}+4^{\mathrm{c}}$ & $100^{\mathrm{c}}$ & $51.4^{\mathrm{c}}$ & - & - & - \\
\hline 7 & $\beta$-caryophyllene $\mathrm{g}^{\mathrm{g}}$ & $250^{f}$ & $128.4 \pm 1.2$ & $26.1 \pm 0.3$ & $44.4 \pm 0.7$ & - & $3.56 \mathrm{e}+4$ & 4 & 284.8 & - & - & - \\
\hline 8 & $\beta$-caryophyllene $\mathrm{g}^{\mathrm{g}}$ & $50^{\mathrm{f}}$ & $28.2 \pm 0.5$ & $25.4 \pm 0.8$ & $47.9 \pm 0.9$ & - & $2.48 \mathrm{e}+4$ & 19 & - & - & - & - \\
\hline 9 & $\beta$-caryophyllene & 48.8 & $34.4 \pm 0.1$ & $25.7 \pm 0.8$ & $69.7 \pm 1.1$ & 16.8 & $3.47 \mathrm{e}+4$ & 10 & 188.4 & 48.1 & 401.8 & 46.9 \\
\hline 10 & $\beta$-caryophyllene $\mathrm{g}$ & 50.7 & $27.8 \pm 0.2$ & $25.9 \pm 0.4$ & $71.4 \pm 0.9$ & 32.8 & $2.76 \mathrm{e}+4$ & 11 & 220.6 & 49.9 & 416.8 & 52.9 \\
\hline 11 & Limonene $\mathrm{g}$ & $250^{f}$ & $142.0 \pm 0.3$ & $26.3 \pm 0.4$ & $49.3 \pm 1.0$ & - & $3.26 \mathrm{e}+4$ & 17 & 861.6 & - & - & - \\
\hline 12 & Limonene $^{\mathrm{g}}$ & $50^{\mathrm{f}}$ & $54.1 \pm 0.5$ & $25.5 \pm 0.5$ & $53.7 \pm 1.3$ & - & $1.51 \mathrm{e}+4$ & 48 & $79.2^{\mathrm{e}}$ & - & - & - \\
\hline 13 & Limonene $^{\mathrm{g}}$ & $50^{\mathrm{f}}$ & $32.1 \pm 0.1$ & $25.3 \pm 0.2$ & $53.5 \pm 0.6$ & - & $1.67 e+4$ & 47 & 65.6 & - & - & - \\
\hline 14 & Limonene ${ }^{g}$ & 52.1 & $36.7 \pm 0.3$ & $25.5 \pm 0.7$ & $73.3 \pm 2.3$ & 55.1 & - & - & - & & & - \\
\hline
\end{tabular}

to $\mathrm{ppbV}$ via both experimental calibration and theoretical calculation using the methods described in Jenkin et al. (2012).

\subsection{Offline analysis: Fourier Transform Ion Cyclotron Resonance Mass Spectrometry}

Aerosol samples were collected onto $47 \mathrm{~mm}$ quartz fibre filters (Whatman) at a flow rate of $3 \mathrm{~m}^{3} \mathrm{~min}^{-1}$. For this purpose, filters were placed in a holder, positioned in the chamber vent line. After sampling, filters were immediately placed in pre-cleaned glass vials and stored below $-18^{\circ} \mathrm{C}$ until analysis. Approximately an area of 7/8th of the filter sample was extracted into high purity water, filtered and reduced to $1 \mathrm{~mL}$ using a vacuum solvent evaporator (Biotage, Sweden) and the remaining portion retained for other analysis. In total 8 filters were analysed, corresponding to the experiments labelled in Table 1.

Samples were analysed at high mass resolution using a Bruker APEX 9.4 T Fourier Transform Ion Cyclotron Resonance Mass Spectrometer. Extracts were sprayed at a flow rate of $2 \mu \mathrm{L} \mathrm{min}^{-1}$, into an Apollo II electrospray interface with ion funnelling technology. Spectra were acquired in both positive and negative ion mode over the scan range $\mathrm{m} / z$ 100-3000 using the following MS parameters: nebulising gas flow $0.9 \mathrm{~L} \mathrm{~min}^{-1}$, drying gas flow $5 \mathrm{~L} \mathrm{~min}^{-1}$, drying temperature $190^{\circ} \mathrm{C}$, collision cell accumulation $0.05-0.5 \mathrm{~s}$, and data acquisition size $2 \mathrm{Mb}$ (yielding a target resolution of 130000 at $\mathrm{m} / \mathrm{z}$ 400). Data were analysed using DataAnalysis 4.0 software (Bruker Daltonics, Bremen, Germany). The instrument was calibrated using protonated (positive ion mode) or deprotonated (negative ion mode) arginine clusters.

The data analysis software employed a user-defined set of conditions to determine the molecular formulae. For the analysis reported in this paper, the following molecular configurations were allowed; unlimited numbers of $\mathrm{C}, \mathrm{H}$ and $\mathrm{O}$ and $0-3$ nitrogen. Chemical formulae were assigned to the masses of singly charged ions $100<m / z<600$ after internal recalibration using fatty acid signals (a solvent contaminant present in all samples) and a maximum error of $5 \mathrm{ppm}$ for ions with a relative intensity of greater than $0.01 \%$. Isotopic ratios were used for further confirmation of the formulae. Background contaminant peaks also seen in pure water and blank extracted filters were manually removed from the analysis.

For each SOA filter analysed, the molecular formulae were determined using FTICRMS. Compounds were screened to remove unlikely molecular formulae. Compounds were removed from the list if they contained any $\mathrm{H}: \mathrm{C}<0.5$, $\mathrm{O}: \mathrm{C}>3$ or $\mathrm{DBE}>20$. Using the formulae, the intensity weighted mean $\mathrm{O}: \mathrm{C}$ and $\mathrm{H}: \mathrm{C}$ ratios of each sample were determined (Bateman et al., 2010) and these used to calculate the average carbon oxidation state $\left(\overline{\mathrm{OS}_{\mathrm{C}}}\right)$ according to Kroll et al. (2011).

\subsection{Rationale behind the choice of precursors}

The emitted speciation of biogenic VOCs is highly complex, and published studies have typically reported up to ca. 20 species making notable contributions to monoterpene, sesquiterpene and oxygenated VOC fluxes from a variety of vegetation types at a variety of locations (Owen et al., 2001; Boissard et al., 2001; He et al., 2000; Spanke et al., 2001). Because of differences in structure and reactivity, these species are oxidised in the atmosphere on timescales ranging from minutes to days and possess a range of propensities to form SOA, which may exhibit a range of physical properties reflecting its diverse chemical composition. In this study, we have identified a subset of biogenic VOCs with an aim to represent a broad range of emitted species and the corresponding range in the rates and chemical complexity 
of their subsequent degradation. Based on the available information on the atmospheric lifetimes of observed biogenic VOCs with respect to reaction with $\mathrm{OH}$ radicals and $\mathrm{O}_{3}$, and current understanding of their known or probable degradation pathways, it is reasonable to divide the biogenic VOCs into a series of structural subsets possessing similar characteristics (Atkinson and Arey, 2003). As a result, consideration of a single compound from each category provides a reasonable starting point for simplifying the emitted speciation whilst maintaining the range in oxidation timescales and propensities to generate SOA. Table 2 provides a summary of the categories, identifying possible representatives and their atmospheric lifetimes with respect to reaction with $\mathrm{OH}$ and $\mathrm{O}_{3}$ at typical mixing ratios (Atkinson and Arey, 2003). The identified compounds thus provide a series of lower reactivity ( $\alpha$-pinene), very high reactivity ( $\beta$-caryophyllene), intermediate reactivity (limonene, myrcene) and more reactive oxygenated (e.g. linalool) species.

\section{Results and discussion}

\subsection{Gas-phase oxidation and SOA formation characteristics}

Figure 1 shows typical temporal profiles of each of the studied gaseous precursors under lower mixing ratio conditions (see Table 1), along with the concomitant production profile of a selection of their primary oxidation products. Each of the different precursors, (a) $\alpha$-pinene, (b) limonene, (c) myrcene, (d) linalool and (e) $\beta$-caryophyllene, exhibited similar and reproducible oxidation profiles, with mixing ratios decaying to minimal levels between approximately 100 and $200 \mathrm{~min}$ after the start of the photochemistry. Each of the primary oxidation products shown in Fig. 1, i.e. (a) pinonaldehyde, (b) limononaldehyde, (c) 4-vinyl-4-pentenal (d) 4-hydroxy4-methyl-5-hexen-1-al and (e) $\beta$-caryophyllon aldehyde, appeared immediately after lights on, increasing at various rates to peak mixing ratios in the approximate range $4-15 \mathrm{ppbV}$, between 100-200 min. Following each respective product peak and depletion of the precursor, the various primary oxidation products began to decrease in concentration at varying rates as the magnitude of loss processes to secondary products and to the aerosol phase overtook production rates. Similar gas-phase results have been obtained from several other simulation chamber studies investigating biogenic oxidation (Lee et al., 2006b; Ng et al., 2006).

The time taken to reach half of the initial mixing ratio of the individual precursors, its half-life, is an empirical representation of the inverse of the total loss rate of the parent hydrocarbon under the specified experimental conditions. This parameter accounts for losses via reaction with oxidants (e.g. ozone, hydroxyl radical), any potential photolysis and physical losses to the chamber walls. With the exception of $\beta$ caryophyllene, the reported precursors have 10 carbon atoms
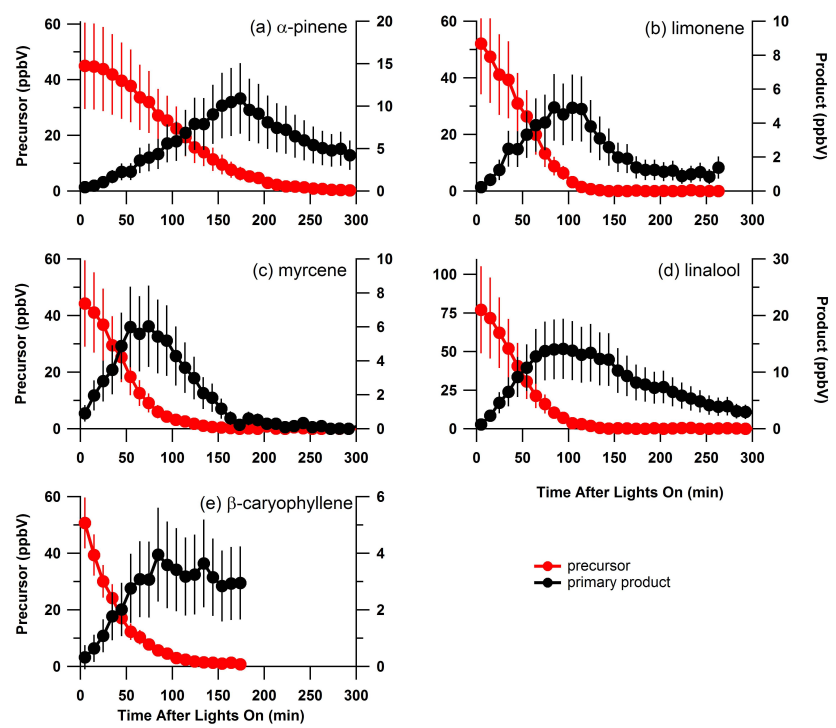

Time After Lights On (min)

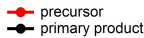

Fig. 1. Temporal profiles of each of the precursors investigated and their primary oxidation products: (a) $\alpha$-pinene and pinonaldehyde (experiment 5, Table 1); (b) limonene and limononaldehyde (experiment 14, Table 1); (c) myrcene and 4-vinyl-4-pentenal (experiment 1, Table 1); (d) linalool and 4-hydroxy-4-methyl-5-hexen-1-al (experiment 3, Table 1); and (e) $\beta$-caryophyllene and $\beta$-caryophyllon aldehyde (experiment 10, Table 1).

and are expected, to a first approximation, to have comparable loss rates to the chamber walls. Thus the observed halflife could be used to infer and compare the overall reactivity of the parent hydrocarbon under the reported experimental conditions. Given the larger molecular size and lower volatility of $\beta$-caryophyllene, its observed half-life is a combination of its loss due to gas-phase oxidation and physical loss to the chamber walls (Matsunaga and Ziemann, 2010). The derived chemical half-life values are summarised in Table 1 , and are broadly consistent with the precursor reactivity data presented in Table 2 and discussed in the rationale section (Sect. 2.5). The shortest lifetimes (i.e. highest loss rates) were observed for $\beta$-caryophyllene, while the longest lifetime was found to be that of $\alpha$-pinene. It has to be noted ozone was not used as a primary oxidant during any of the experiments reported in this study, and it was formed as a result of the photochemistry. There seems to be some difference between the lifetimes of myrcene when higher and lower initial mixing ratios were used. Linalool, on the other hand, does not exhibit the same behaviour, as its lifetimes are comparable under lower and higher initial mixing ratios. It is not possible to attribute these differences to a mechanistic cause given that initial $\mathrm{VOC} / \mathrm{NO}_{\mathrm{x}}$ ratios were different during those experiments and that no explicit degradation mechanisms exist for these compounds.

The SOA production profiles during those same high and low initial mixing ratio experiments are also broadly consistent with the chemical half-life data; i.e. the peak particle 
Table 2. List of all five precursors, structures and reactivity towards $\mathrm{OH}$ and $\mathrm{O}_{3}$ based on reaction lifetimes from Atkinson and Arey (2003).

\begin{tabular}{|c|c|c|c|c|}
\hline Category & $\begin{array}{l}\text { Representative } \\
\text { compound }\end{array}$ & Structure & $\begin{array}{c}\mathrm{OH}^{\mathrm{a}} \text { reaction } \\
\text { lifetime }\end{array}$ & $\begin{array}{c}\mathrm{O}_{3}{ }^{\mathrm{b}} \text { reaction } \\
\text { lifetime }\end{array}$ \\
\hline Bicyclic monoterpene & $\alpha$-pinene & & $2.6 \mathrm{~h}$ & $4.6 \mathrm{~h}$ \\
\hline Monocyclic diene monoterpene & limonene & & $49 \min$ & $2 \mathrm{~h}$ \\
\hline Acyclic triene monoterpene & myrcene & & $39 \mathrm{~min}$ & $50 \mathrm{~min}$ \\
\hline Reactive sesquiterpene & $\beta$-caryophyllene & & $42 \mathrm{~min}$ & $2 \min$ \\
\hline Reactive C10 oxygenates & linalool & & $52 \mathrm{~min}$ & $55 \mathrm{~min}$ \\
\hline
\end{tabular}

number concentration was reached in a relatively shorter time in the higher initial mixing ratio cases compared to the lower ones, as illustrated in Table 1. Further inspection of the times taken to reach peak number concentration indicates that, for the lower initial mixing ratios, the SOA formation is consistent with the gas-phase reactivity of the individual precursors. For example, $\beta$-caryophyllene SOA peak number was the first to be reached, while $\alpha$-pinene SOA was the slowest. Owing to the limited availability of data, SOA mass yield values have been calculated and reported for a subset of experiments. The yield is defined as the percentage ratio of the amount of SOA formed from the oxidation of a given parent compound to the amount of that compound that reacted. The maximum wall-loss corrected SOA mass concentrations are reported in Table 1 and have been used to determine the SOA yield values. Wall-loss rates were determined using a similar approach to that reported by Pfaffenberger et al. (2013), where an exponential decay function is fitted to the mass concentration data to derive a wall loss correction factor. The fit is applied during a period near the end of the experiment, where wall loss is expected to be the dominant process controlling changes in measured SOA mass.

The calculated SOA yield values, reported in Table 1, provide a means of comparing the SOA production for the individual precursors under similar experimental conditions. The yield values reveal that, under the reported conditions, $\beta$-caryophyllene has the highest aerosol formation potential compared to other precursors in this study. Our high yield values (approximately 50\%) are consistent with the literature, where it has been attributed to the high molar mass of the $\beta$-caryophyllene oxidation products, and explained by the presence of two reactive double bonds, which provide more than one site for potential chemical reactions to occur, leading to products with more functional groups and lower vapour pressures (Jaoui et al., 2003; Griffin et al., 1999; Lee et al., 2006a; Alfarra et al., 2012). The data also indicate that myrcene has a similar SOA formation potential to that of $\alpha$ pinene, while SOA yield from linalool is lower. It is worth noting that, as discussed for the gas phase, SOA formation potential appears to be also higher when the same precursor is used at higher initial mixing ratio compared to a lower initial mixing ratio case. The latter observation is consistent with the absorptive partitioning theory (Pankow, 1994).

\subsection{Chemical composition}

Figure 2 shows the mass spectral patterns of the SOA produced during the photooxidation of each of the precursors in the low initial mixing ratio experiments. Spectra are shown for both fresh SOA, formed very early on during the experiments (left panels, averaged over the first 10 min of AMS data in each case), and relatively more aged SOA (right panels), after about four hours of the start of the photooxidation (lights on). All the spectra have been normalised to the total SOA signal; the fractional contribution of each mass fragment to the total SOA signal $\left(f_{m / z}\right)$ is shown and can be used to compare the broad chemical composition of the SOA 


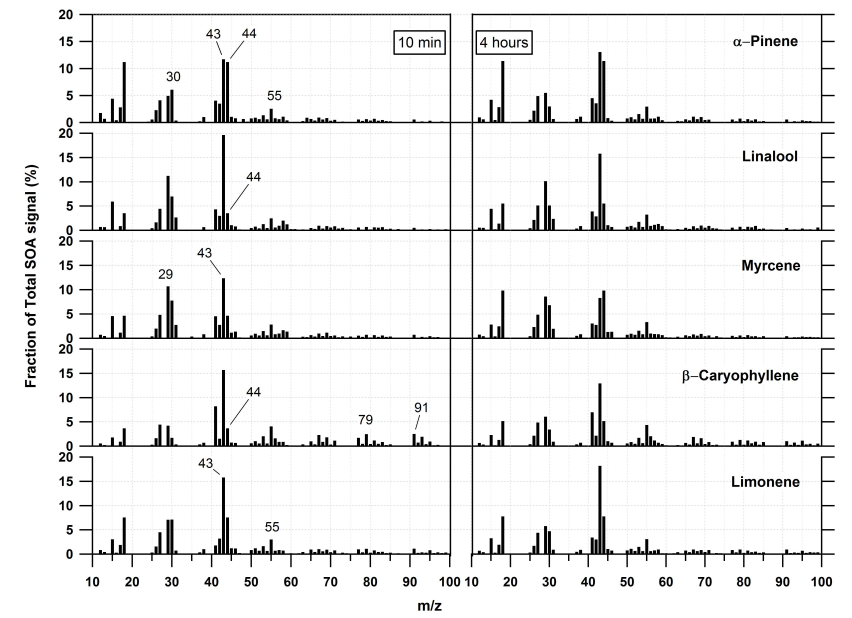

Fig. 2. Mass spectral patterns of SOA from the photooxidation of biogenic VOCs (data from the lower initial mixing ratio experiments reported in Table 1). The left-hand panels include spectra measured during the first $10 \mathrm{~min}$ of SOA formation, while those measured after $4 \mathrm{~h}$ of photooxidation are displayed in the right-hand panels. Each spectra has been normalised to the total SOA signal.

formed from the photooxidation of each precursor and also changing chemical composition of each SOA system as a function of photochemical ageing. Detailed inspection of the mass spectral patterns reveals that one of the most significant differences among the various SOA systems is the fractional contributions of mass fragments 43 and 44 to the total SOA signal (i.e. $f_{43}$ and $f_{44}$ ). This is a recognised feature of most AMS data sets and the two mass fragments have been widely used to discuss the level of oxygenation of organic aerosols in many laboratory and field studies (Ng et al., 2010; Alfarra et al., 2004). Other differences among the mass spectral patterns of the five SOA systems appear in $\mathrm{m} / \mathrm{z}$ range between 55 and 60, where linalool and myrcene SOA share similar patterns, but which are different to those observed for the other precursors. $\beta$-caryophyllene SOA has a higher contribution from relatively larger mass fragments, including 77, 79, 81 and 83 as well as 91, 93 and 95 . As a result of the nature of electron impact ionisation and the lack of preseparation methods, it is not possible to associate these mass fragments with specific compounds. However, some of those fragments (e.g. $m / z 77$ and 91) are traditionally associated with the fragmentation of aromatic compounds. A comparison of the mass spectral patterns of the fresh and aged SOA produced by each precursor shows hardly any change, with the exception of the changes in $f_{43}$ and $f_{44}$, discussed below.

The fractional contributions of mass fragments 43 and 44 to the total organic signal ( $f_{43}$ and $f_{44}$ ) have been widely used as markers for "less" and "more" oxygenated organic compounds, respectively, in several laboratory and field studies using the aerosol mass spectrometer ( $\mathrm{Ng}$ et al., 2010; Pfaffenberger et al., 2013; Alfarra et al., 2004, 2006; Zhang et al., 2005; Lanz et al., 2007). The former is mostly as-

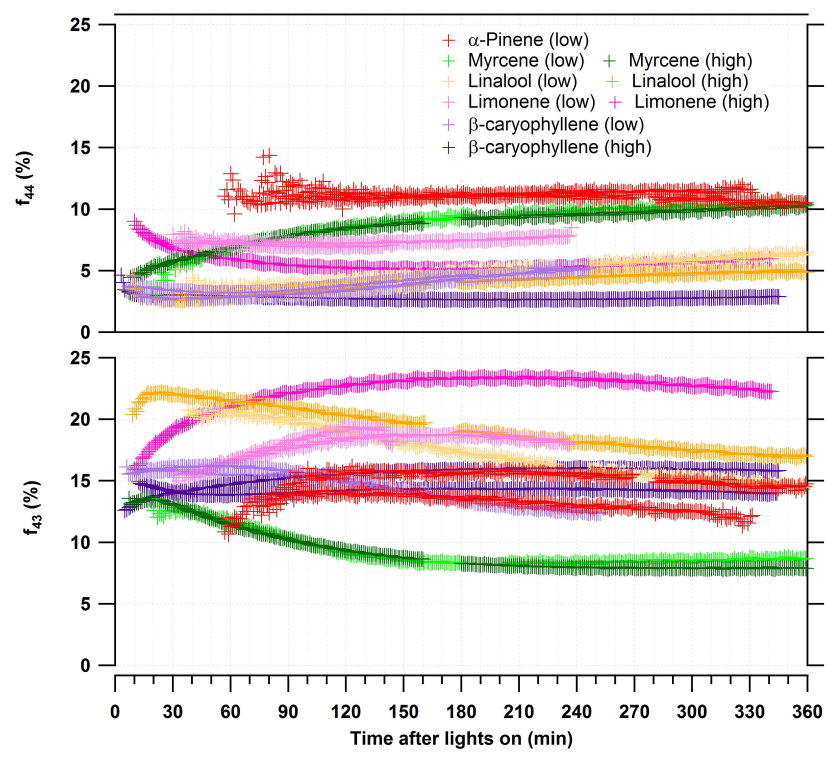

Fig. 3. Evolution of the $f_{44}$ and $f_{43}$ with photooxidation for low and high initial VOC mixing ratio experiments.

sociated with carbonyl-based compounds, while $f_{44}$ is a marker for compounds containing di- and poly-carboxylic acid groups (Alfarra, 2004; Takegawa et al., 2007). It has been shown that atmospheric ageing leads to an increase in $f_{44}$ (Alfarra et al., 2004; Aiken et al., 2008; de Gouw et al., 2005); therefore, this value is considered as an indicator of atmospheric ageing. The temporal trends of $f_{44}$ for all biogenic SOA systems studied here are shown in the top panel of Fig. 3, both for the low and high initial precursor mixing ratio experiments. Similarly, those of $f_{43}$ are shown in the bottom panel of the same figure. It can quickly be noticed that the different SOA produced using the selected biogenic precursors have a wide range of chemical characteristics expressed by $f_{44}$ and $f_{43}$ both in terms of actual values as well as temporal behaviour as a function of photochemical ageing. For example, the $\beta$-caryophyllene and linalool SOA show the lowest values of $f_{44}$ and these values appear to be only slightly influenced by photochemical ageing. On the other hand, photochemical ageing appears to more than double the value of $f_{44}$ of freshly produced myrcene SOA after about $6 \mathrm{~h}$ of processing (from about 4 to $10 \%$ ). SOA produced from low initial mixing ratio of $\alpha$-pinene and limonene have relatively high $f_{44}$ values (11 and $7 \%$, respectively) compared to the other SOA systems studied here; however these values do not change much as a result of photochemical ageing. Linalool and $\beta$-caryophyllene SOA exhibit relatively low $f_{44}$ values around $4 \%$, which increase slightly to about $5-6 \%$ as a result of photochemical ageing.

The initial fractional contribution values of mass fragment $43\left(f_{43}\right)$ span quite a wide range from $12-22 \%$, changing to $8-23 \%$ after six hours of photochemical ageing. The trends of $f_{43}$ appear to show, to a large extent, a reverse 
pattern of those for $f_{44}$. With the exception of limonene SOA, $f_{43}$ values decrease with photochemical ageing. Such trends are consistent with processing of carbonyl-containing compounds to more oxidised carboxylic acid-containing compounds. An explanation of the reverse pattern observed for limonene SOA (i.e. the increase in the $f_{43}$ fraction with photochemical ageing) is not obvious. These results show that composition of SOA generated from a single biogenic precursor cannot and should not be used as a proxy for biogenic SOA in general. Additionally, the values of $f_{44}$, which are widely used in the literature to indicate the level of oxygenation of organic aerosol in field and laboratory studies, are very much dependent on the type of precursor, the extent of photochemical ageing as well as on the initial experimental conditions.

Another intriguing observation in this data set is that the effect of initial precursor mixing ratio (in this study 50 vs. $250 \mathrm{ppbV}$ ) on the chemical characteristics of the produced SOA represented by $f_{44}$ and $f_{43}$ is not uniform and does not appear to follow a specific pattern. Previous studies reported an increase in the $f_{44}$ value for $\alpha$-pinene SOA as mass loading or initial precursor mixing ratio were decreased (Duplissy et al., 2008; Shilling et al., 2009; Pfaffenberger et al., 2013). Our work shows that although this appears to be also true for relatively aged linalool, limonene and $\beta$-caryophyllene SOA (Alfarra et al., 2012), it is not necessarily always the case for SOA generated from other biogenic precursors. For example, changing the initial myrcene mixing ratio does not appear to have a measurable effect on the $f_{44}$ and $f_{43}$ values of the produced SOA regardless of photochemical ageing. The results also indicate that changing the initial precursor mixing ratio does not influence the $f_{44}$ value for freshly produced SOA in most of the cases reported here. Of course, this finding is limited to the mixing ratio ranges explored in the current study and characterisation of the variation in composition across a broader range of initial mixing ratios is required.

In order to compare the composition of the SOA particles generated from the five biogenic precursors studied here in the context of the composition of ambient organic aerosols, a 2-dimensional representation of the relationship between $f_{44}$ and $f_{43}$ is shown in Fig. 4. The dotted lines in this figure mark the well-defined triangular space occupied by data points from a large number of ambient data sets collected at a large number of locations in the Northern Hemisphere and discussed in detail by $\mathrm{Ng}$ et al. (2010). Data of more aged, and hence more oxygenated and by inference less volatile, organic aerosols tend to show an increasing value of $f_{44}$ and a decreasing value of $f_{43}$ and therefore appear more towards the top of the triangle-shaped space. This space is dominated by the AMS factor defined as low volatility oxygenated organic aerosols (LV-OOA), while data in the lower half of the triangle is more representative of the AMS defined factor as semi-volatile oxygenated organic aerosols (SV-OOA) (Jimenez et al., 2009; Ng et al., 2010). The chamber generated SOA data from the photooxidation of myrcene and

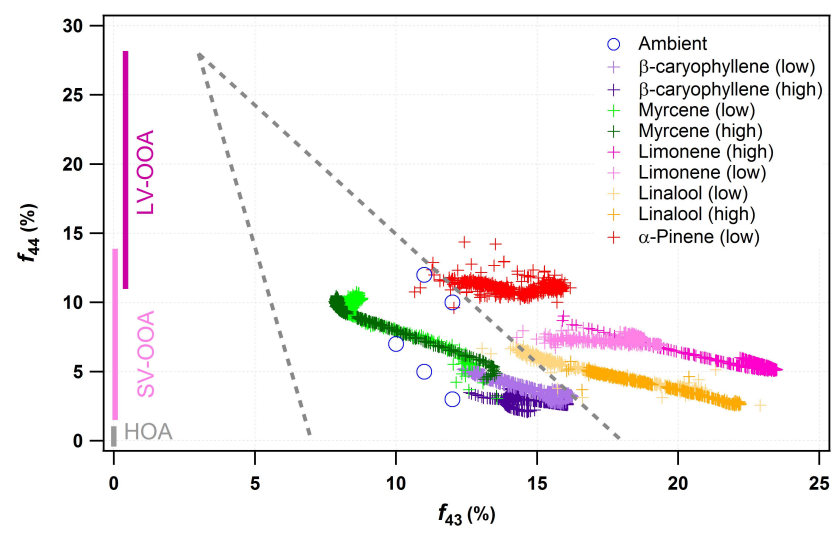

Fig. 4. A 2-dimensional representation of $f_{44}$ and $f_{43}$ for all SOA systems in this study. The dashed line represents the boundaries of this relationship based on previously published ambient data sets by $\mathrm{Ng}$ et al. (2010). The open circles are measurements conducted at biogenically-influenced locations in North America and Europe, as compiled by $\mathrm{Ng}$ et al. (2010).

$\beta$-caryophyllene are located in the bottom right corner of the ambient triangle, indicating that the composition of those two SOA systems is consistent with ambient organic aerosols characterised by the SV-OOA factor (Ng et al., 2010). It can also be seen that photochemical ageing leads to a more significant processing of the myrcene SOA particles, transforming their composition towards being more LV-OOA and less SV-OOA. On the other hand, the composition of SOA particles produced from the photooxidation of limonene, linalool and $\alpha$-pinene appear to be less representative of ambient organic aerosol composition as their data points fall outside the ambient triangle featuring higher values of $f_{43}$. However, photochemical ageing of those three systems does, indeed, help transform their composition, bringing it closer to the edge of the ambient triangle.

The representation of the chamber SOA data in Fig. 4 confirms our earlier point regarding the wide range of chemical characteristics exhibited by chamber SOA, depending on the choice of precursor and the initial experimental conditions. Care should be taken not to assume that SOA produced from a specific precursor under specific conditions could be used as a proxy for biogenic SOA in general. The data points marked by open circles in Fig. 4 represent SVOOA components from organic aerosols measured at sites likely to have strong influence from biogenic SOA sources: Duke Forest, Hyytiälä, Thompson Farm, Chebogue, and Egbert (Allan et al., 2006; Williams et al., 2007; Cottrell et al., 2008; Raatikainen et al., 2010; Slowik et al., 2010), as reported by Ng. et al. (2010). Similar to our biogenic SOA data, these do not appear to be located at a specific area within the lower half of the triangle space, possibly indicating the lack of universal mass spectral signature, and therefore chemical composition, of fresh biogenic SOA. This implies that, unlike aged secondary organic aerosols, choosing or claiming 


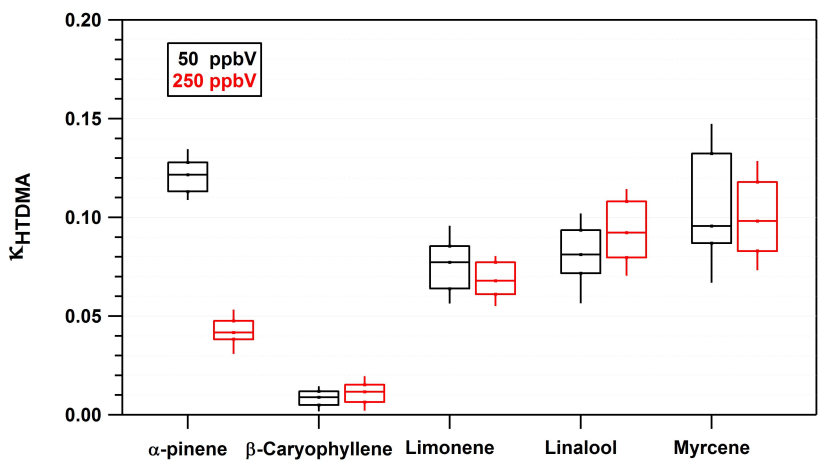

Fig. 5. A box and whisker plot illustrating the observed range of hygroscopic properties, represented by $\kappa_{\text {HTDMA }}$, for all selected dry particle diameters for particles generated from each initial mixing ratio of the studied precursors.

a representative mass spectral signature (chemical composition) for fresh biogenic secondary organic aerosol is not likely to be a straightforward task as it appears to be dependent on location and conditions.

\subsection{Hygroscopic properties}

Hygroscopicity measurements were carried out during one higher and one lower mixing ratio experiments for each SOA precursor, except for limonene experiments, which were repeated three times, and $\beta$-caryophyllene experiments, which were repeated four times. For all five precursors investigated, the HTDMA consistently measured a narrow particle growth factor distribution at each selected dry particle diameter, indicating that particles of the same size have similar composition at any given time (i.e. internally mixed). Being internally mixed the hygroscopicity of particles in the chamber of a given size can be well described by a single $\kappa$ value (Petters and Kreidenweis, 2007) calculated from the mean of the fitted growth factor probability density function (GFPDF) (Gysel et al., 2009). Hereafter hygroscopic growth factor refers to the mean of the GF-PDF unless otherwise stated. Figure 5 illustrates the observed range of hygroscopic properties, represented by $\kappa_{\text {HTDMA }}$, for all selected dry particle diameters $\left(D_{0}\right)$ for particles generated from each initial mixing ratio of each precursor. The $\beta$-caryophyllene produced the least hygroscopic particles $\left(\kappa_{\text {HTDMA }} \sim 0.01\right.$ ), while $\alpha$ pinene, limonene, linalool and myrcene produced particles with higher hygroscopicity $\left(\kappa_{\mathrm{HTDMA}} \sim 0.03\right.$ to 0.14 ). The hygroscopic behaviour of each precursor is discussed in more detail below. Table 3 summarises the hygroscopic properties, represented by $\kappa_{\mathrm{HTDMA}}$, and range of growth factors observed for each precursor.
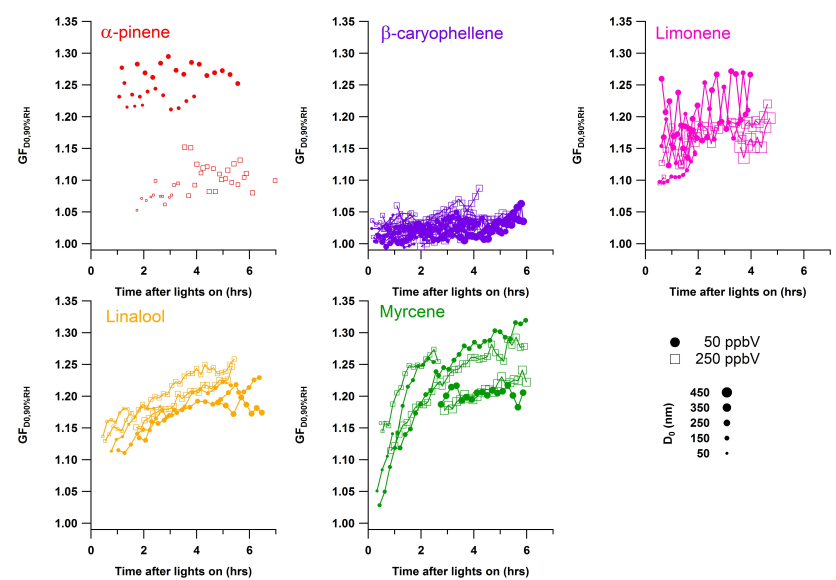

Fig. 6. Temporal profiles of hygroscopic growth factors at $90 \% \mathrm{RH}$ $\left(\mathrm{GF}_{D 090 \%}\right)$ of the SOA particles from the five studied biogenic precursors.

\subsection{1 $\alpha$-Pinene SOA}

Photooxidation of $50 \mathrm{ppbV} \alpha$-pinene generated particles with higher hygroscopic growth factors compared to those produced using the $250 \mathrm{ppbV}$ conditions. The hygroscopicity of the particles averaged over each hour of the experiment tended to increase throughout the $50 \mathrm{ppbV}$ experiment, in contrast to the $250 \mathrm{ppbV}$ experiment where the hourly averaged hygroscopicity increased before stabilising after approximately $4 \mathrm{~h}$ of photooxidation (Fig. 6).

\subsection{2 $\quad \beta$-Caryophyllene SOA}

Photooxidation of 50 and $250 \mathrm{ppbV} \beta$-caryophyllene produced the least hygroscopic particles compared to all other precursors in this study. The average hygroscopic growth factors were similar for both initial mixing ratios. The $\kappa_{\text {HTDMA }}$ averaged over each hour of the experiment appeared to increase slightly with time, $\sim 0.005$ during a typical experiment, but this increase was generally within the measurement uncertainty (Fig. 6). The $\beta$-caryophyllene hygroscopicity measurements shown here have also been presented by Hamilton et al. (2011) in the context of utilising $\beta$ caryophyllene to generate biogenic organic seed particles for chamber experiments, and by Alfarra et al. (2012) in the context of investigating the effect of initial VOC mixing ratio on hygroscopic properties.

\subsubsection{Limonene SOA}

Photooxidation of $50 \mathrm{ppbV}$ limonene produced slightly more hygroscopic particles compared to those produced in the $250 \mathrm{ppbV}$ case. The $50 \mathrm{ppbV}$ experiment showed the average $\kappa_{\text {HTDMA }}$ over $1 \mathrm{~h}$ intervals increasing slightly by 0.02 from hour 1 to hour 4 . The $250 \mathrm{ppbV}$ experiment showed the 
Table 3. Mean growth factor and $\kappa$ values derived from the HTDMA measurements at $90 \%$ RH for the $50 \mathrm{ppbV}$ and $250 \mathrm{ppbV}$ initial precursor mixing ratios.

\begin{tabular}{lccc|ccc}
\hline \multirow{2}{*}{ Precursor } & \multicolumn{3}{c}{$50 \mathrm{ppbV}$} & \multicolumn{3}{c}{$250 \mathrm{ppbV}$} \\
\cline { 2 - 7 } & $\mathrm{GF}_{90 \% \mathrm{RH}}$ & Range & $\kappa_{\text {HTDMA }}$ & GF$_{90 \% \mathrm{RH}}$ & Range & $\kappa_{\text {HTDMA }}$ \\
\hline$\alpha$-pinene & 1.27 & $1.25-1.29$ & 0.121 & 1.08 & $1.07-1.13$ & 0.042 \\
$\beta$-caryophyllene & 1.02 & $1.01-1.04$ & 0.009 & 1.03 & $1.01-1.05$ & 0.011 \\
Limonene & 1.17 & $1.11-1.23$ & 0.077 & 1.15 & $1.13-1.19$ & 0.069 \\
Linalool & 1.18 & $1.13-1.22$ & 0.082 & 1.17 & $1.15-1.24$ & 0.090 \\
Myrcene & 1.21 & $1.12-1.29$ & 0.101 & 1.19 & $1.16-1.27$ & 0.098 \\
\hline
\end{tabular}

average $\kappa_{\text {HTDMA }}$ over $1 \mathrm{~h}$ intervals increasing slightly by 0.02 from hour 1 to hour 5 (Fig. 6).

\subsubsection{Linalool SOA}

The average hygroscopic growth factors of particles produced from the photooxidation of 50 and $250 \mathrm{ppbV}$ linalool were similar. However particles in the $250 \mathrm{ppbV}$ case exhibited a slightly higher range. The hygroscopicity increased throughout experiments, where for the $50 \mathrm{ppbV}$ case the average $\kappa_{\text {HTDMA }}$ over $1 \mathrm{~h}$ intervals increased by 0.03 from hour 1 to hour 5 . The average $\kappa_{\text {HTDMA }}$ for $250 \mathrm{ppbV}$ experiment, on the other hand, increased over $1 \mathrm{~h}$ intervals by 0.04 from hour 1 to hour 5 (Fig. 6). After $\sim 1.5 \mathrm{~h}, 150 \mathrm{~nm}$ and $200 \mathrm{~nm}$ diameter particle were selected alternately by the HTDMA. A consistent difference between the hygroscopicity of the two selected particle sizes was observed for $\sim 0.01$ ( $\left.\kappa_{\text {HTDMA }}\right)$, indicating that there may be differences in their composition; this though is within the measurement uncertainty of the TDMA (gf \pm 0.02 ) (Massling et al., 2011).

\subsubsection{Myrcene SOA}

The growth factors of particles produced form the photooxidation of $50 \mathrm{ppbV}$ myrcene appeared to be slightly higher than those produced in the $250 \mathrm{ppbV}$ experiment. In both cases, there was a measurable difference in the hygroscopicity of particles sampled alternately at different sizes. The difference was typically between 0.03 and $0.05\left(\kappa_{\text {HTDMA }}\right)$ when alternating between sampling different sizes. When a larger size was selected the hygroscopicity was always lower than that of the smaller size sampled before and after. The hygroscopicity of particles at single selected size increased with time throughout the myrcene experiments (Fig. 6). The change in particle hygroscopicity was $\sim 0.1$ ( $\kappa_{\text {HTDMA }}$ ) from the start to the end of the experiments.

\subsubsection{Trends in hygroscopicity}

For each of the five precursors, the hygroscopicity of particles sampled throughout the experiments tended to increase, based on the hourly averaged $\kappa_{\text {HTDMA }}$ values during each experiment for all dry sizes (Fig. 6). Small particles sampled by the HTDMA at any particular time have been produced later (and exposed to shorter gaseous OVOC histories) than larger particles. Considering each selected dry size separately, there is correlation between (increasing) hygroscopicity and time (i.e. degree of oxidation). For $\beta$-caryophyllene the correlation between $\kappa_{\text {HTDMA }}$ and time is sometimes large $\left(r^{2}>0.9\right)$ but at other times much lower, whilst for limonene, linalool and myrcene there is generally a strong $\left(r^{2}>0.9\right)$ correlation of $\kappa_{\text {HTDMA }}$ and time. The increases of $\kappa_{\text {HTDMA }}$ with time indicates that SOA formed from molecules that partition from the gas phase later in the experiments are more hygroscopic. Given that the observed change in $\kappa_{\text {HTDMA }}$ is small during $\beta$-caryophyllene experiments (and of similar magnitude to the HTDMA's precision), it is only possible to assert that the hygroscopicity of molecules formed throughout the $\beta$ caryophyllene experiments is identical within measurement uncertainty.

\subsection{CCN activity}

Critical supersaturations derived from the $D_{50}$ were obtained for $50 \mathrm{ppbV} \alpha$-pinene, $\beta$-caryophyllene, limonene, linalool and myrcene experiments. $D_{50}$ measurements were also obtained for $250 \mathrm{ppbV}$ linalool and myrcene experiment. The $\mathrm{CCNc}$ data set is significantly limited compared to other data sets due to the fact that if a too high or too low supersaturation is set in the $\mathrm{CCNc}$, either all or none of the particles activate over the narrow size distribution in the chamber and a $D_{50}$ cannot be determined. Table 4 summarises the range of $\kappa_{\mathrm{CCN}}$ values. Figure 7 illustrates the lack of temporal trends in $\mathrm{CCN}$ activity; this observation, though, is from a much more limited data set than the HTDMA. The higher mixing ratio experiments (linalool and myrcene) resulted in slightly lower $\kappa_{\mathrm{CCN}}$ values than their corresponding $50 \mathrm{ppbV}$ experiments.

\subsection{Reconciliation of $\kappa_{\mathrm{HTDMA}}$ and $\kappa_{\mathrm{CCN}}$}

In general, the average $\kappa$ values derived from the HTDMA and $\mathrm{CCNc}$ are similar for each precursor. For $50 \mathrm{ppbV} \alpha-$ pinene, the HTDMA values are very slightly lower than those derived from the $\mathrm{CCNc}$, the mean $\kappa_{\mathrm{HTDMA}} 0.12 \mathrm{com}-$

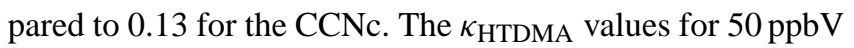


Table 4. Mean and range of kappa values derived from the $\mathrm{CCNc}$ measurements for the $50 \mathrm{ppbV}$ and $250 \mathrm{ppbV}$ initial precursor mixing ratios.

\begin{tabular}{lrr|rr}
\hline \multirow{2}{*}{ Precursor } & \multicolumn{2}{c|}{$\kappa_{\mathrm{CCN}}$} & \multicolumn{2}{|c}{$10-90$ th percentile range } \\
\cline { 2 - 5 } & $50 \mathrm{ppbV}$ & $250 \mathrm{ppbV}$ & $50 \mathrm{ppbV}$ & $250 \mathrm{ppbV}$ \\
\hline$\alpha$-pinene & 0.13 & - & $0.10-0.16$ & - \\
$\beta$-caryophyllene & 0.009 & - & $0.009-0.014$ & - \\
Limonene* & 0.06 & - & $\mathrm{NA}$ & - \\
Linalool & 0.12 & 0.10 & $0.10-0.15$ & $0.06-0.14$ \\
Myrcene & 0.12 & 0.10 & $0.06-0.17$ & $0.06-0.13$ \\
\hline
\end{tabular}

* Derived from limited number of measurements.

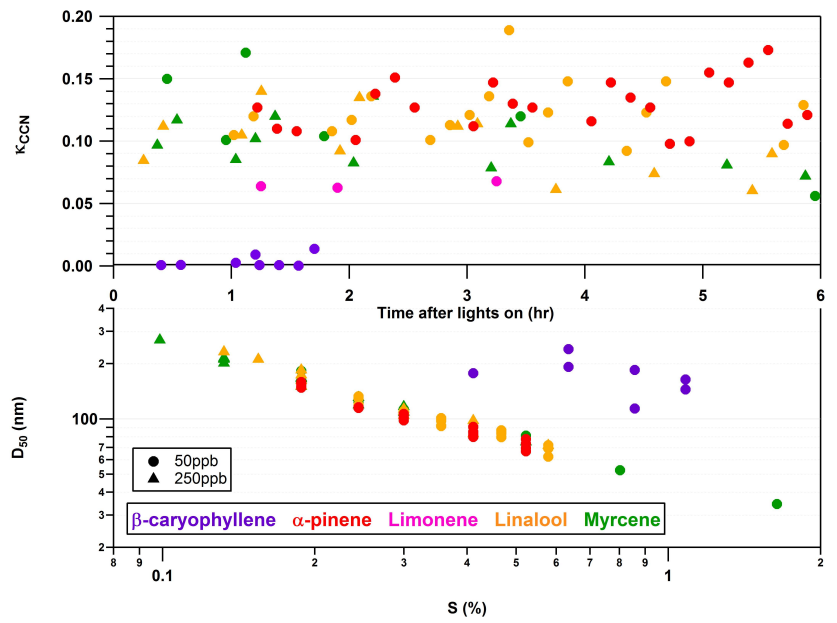

Fig. 7. Temporal profiles of CCN activity $\left(\kappa_{\mathrm{CCN}}\right)$ of the SOA particles from the five studied biogenic precursors (top panel). The relationship between the size at which $50 \%$ of the particles activated $\left(D_{50}\right)$ and supersaturation for all of the SOA systems is shown in the bottom panel.

$\beta$-caryophyllene are slightly higher than those derived from the CCNc. The mean $\kappa_{\text {HTDMA }}$ values are 0.014 compared to 0.009 for the CCNc. The $\kappa_{\text {HTDMA }}$ values for $50 \mathrm{ppbV}$ limonene SOA cover the range of $\kappa$ values derived from the $\mathrm{CCNc}$, although it should be noted that only 3 data points were collected from the $\kappa_{\mathrm{CCN}}$. The $\kappa_{\mathrm{HTDMA}}$ values for $50 \mathrm{ppbV}$ linalool SOA are lower (mean 0.08) than those derived from the $\mathrm{CCNc}$ (mean 0.12). Similarly, the $\kappa_{\text {HTDMA }}$ for $50 \mathrm{ppbV}$ myrcene SOA (mean 0.10) are slightly lower than those derived from the $\mathrm{CCNc}$ (mean 0.12), but the range of $\kappa$ values is similar. The mean $\kappa_{\text {HTDMA }}$ values for the $250 \mathrm{ppbV}$ myrcene and linalool experiments are close to those observed by the CCNc.

In summary, $\kappa_{\text {HTDMA }}$ values derived $50 \mathrm{ppbV} \alpha$-pinene, linalool, and myrcene SOA appear slightly lower than those derived from the CCNc. This difference is largest in the first hours of the experiments; as the $\kappa_{\text {HTDMA }}$ values increase towards the end of the experiments, the difference between the CCNc and HTDMA become smaller. The $\kappa$ values for $250 \mathrm{ppbV}$ linalool and myrcene SOA are similar. The

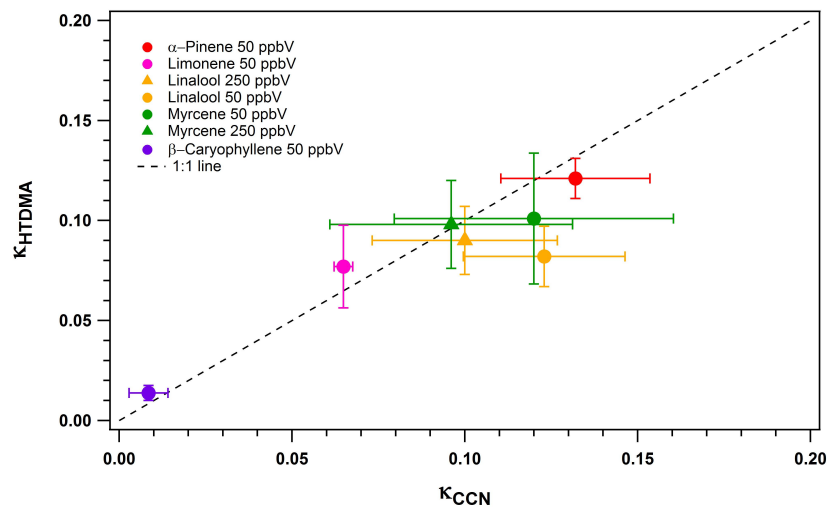

Fig. 8. Reconciliation of mean kappa values from HTDMA and CCN measurements. The vertical and horizontal variability bars represent one standard deviation for each measurement.

$50 \mathrm{ppbV} \beta$-caryophyllene $\kappa_{\text {HTDMA }}$ values are slightly higher than $\kappa_{\mathrm{CCN}}$.

It should be noted that, in both HTDMA and CCNc instruments, the RH of the SOA sample is actively controlled but not the saturation ratio of any other semi-volatile component. A smog chamber is typically an extensive continuous source of vapours of ranging volatility. It is assumed that the particles have equilibrated with the RH in the sub-saturated measurement in the HTDMA (Swietlicki et al., 2008) and supersaturated measurement in the $\mathrm{CCNc}$ (Roberts and Nenes, 2005). Since there is no active control of other semi-volatile components (i.e SVOCs), these molecules are free to condense or evaporate towards their equilibrium concentrations in the measurement timescales of the instruments (Topping and McFiggans, 2012). Therefore, hygroscopic growth and cloud activation of SOA particles are likely to be substantially impacted by the tendency of these semi-volatile molecules towards co-equilibration during the drying prior to initial size selection and humidification in determining their sub-saturated growth or cloud activation potential. Given the lack of active control of semi-volatile compound saturation ratios and the very different values likely to be experienced in each instrument, it may be considered surprising that the relatively large scatter in the data shown in Fig. 8 is not larger.

Previous work by Good et al. (2010c) reported results from three different HTDMAs and found that the ability of the single parameter $\kappa$ model to predict cloud activation behaviour of secondary organic aerosol particles produced by the chamber photo-oxidation of $\alpha$-pinene was dependent on the instrument used to measure sub-saturated hygroscopicity and the relative humidity used to provide the model input. However, agreement was observed for inorganic salt solution particles, which were measured by all instruments in agreement with theory. In that study, the reported $\kappa_{\text {HTDMA }}$ values were between 0.04 and 0.1 , depending on the instrument used for measurements. In addition, differences in the subsaturated hygroscopic growth were observed when different 


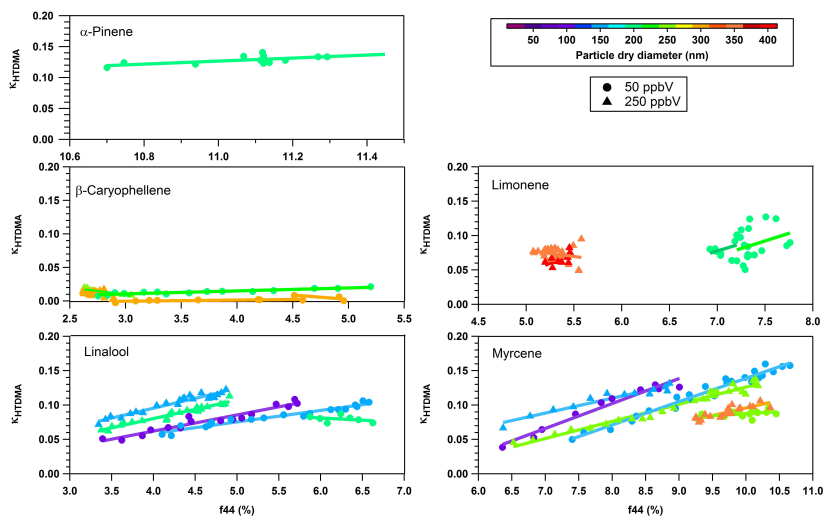

Fig. 9. The relationship between hygroscopicity of particles of a single size (represented by $\kappa_{\text {HTDMA }}$ ) and $f_{44}$ measured simultaneously by the ToF-AMS for each precursor at both high and low initial mixing ratios. The linear fit parameters and coefficient of determination $\left(r^{2}\right)$ for each selected particle size are listed in Table 5.

initial mixing ratios of $\alpha$-pinene were used. The reported $\kappa_{\mathrm{CCN}}$ values for the same experiments were very close to 0.1 and did not seem to change with the initial mixing ratio of $\alpha$ pinene. The study concluded that the difference in HTDMA data from validated and extensively used instruments meant that it could not be stated with certainty the detail required to predict the CCN activity from sub-saturated hygroscopicity. Several other studies have compared sub- and super-saturated hygroscopic properties of $\alpha$-pinene SOA and reported variable findings. For example, both Duplissy et al. (2008) and Jurányi et al. (2009) reported that $\kappa_{\mathrm{HTDMA}}$ and $\kappa_{\mathrm{CCN}}$ could be reconciled within experimental uncertainties for SOA produced from photooxidation of $\alpha$-pinene (with initial precursor concentration of 10-270 ppb). In contrast, Prenni et al. (2007) observed discrepancies for SOA produced from ozonolysis of $\alpha$-pinene, although the initial precursor concentration was much greater (>400 ppb) than other studies. Massoli et al. (2010) found that $\kappa_{\text {HTDMA }}$ values for $\alpha$-pinene SOA were consistently lower than $\kappa_{\mathrm{CCN}}$. It has to be noted that the SOA particles investigated in the studies listed here were all generated using different experimental conditions, in terms of initial concentrations, oxidation regimes and oxidant levels. It has been suggested that measurements of hygroscopic growth factors (HGF) at RH $>95 \%$ are needed to determine the steepness of the HGF curve close to the point of CCN activation (Juranyi et al., 2009; Wex et al., 2009), and that factors such as gas-phase precursor concentration, molecular size, solubility and functional groups should be considered in predicting the CCN activity of SOA particles (Duplissy et al., 2008; Petters and Kreidenweis, 2008; Petters et al., 2009a, b; Good et al., 2010b, c; Poulain et al., 2010).

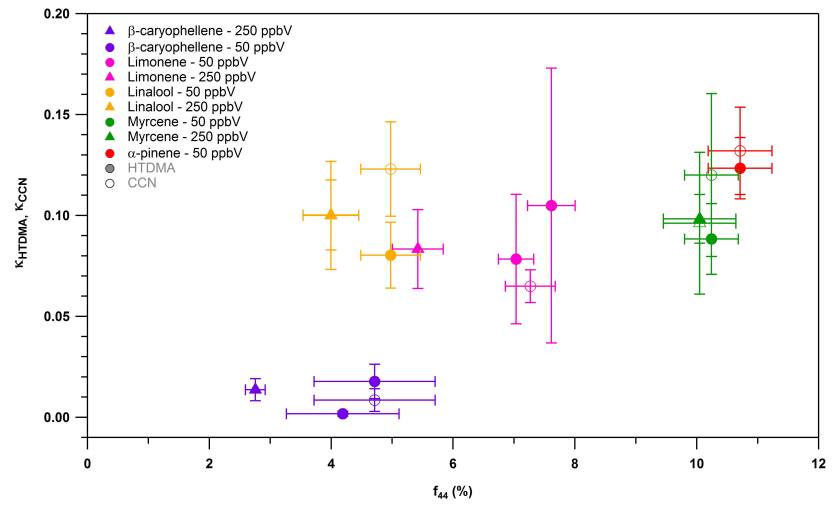

Fig. 10. The relationship between sub- and super-saturated water uptake of SOA particles and their level of oxidation. The $\kappa_{\mathrm{HTDMA}}$ (open symbols) and $\kappa_{\mathrm{CCN}}$ (filled symbols) are mean values measured for the largest size during the final hour of each experiment. The level of oxidation is inferred from the mean values of $f_{44}$ during the corresponding period. The variability bars are $( \pm 3$ s.d.) of the measurements.

\subsection{Relating hygroscopicity to composition}

Increases in particle hygroscopicity during chamber experiments of this type (i.e. single VOC oxidation) have been shown to relate to the changing composition of the sampled particles with time (Massoli et al., 2010; Duplissy et al., 2011; Juranyi et al., 2009; Lambe et al., 2011). Specifically, the relative oxidation of the molecules that make up organic particles has been observed to correlate with their hygroscopicity within individual systems (e.g. $\alpha$-pinene, isoprene, trimethylbenzene and $m$-xylene) reported in those studies. The extent of oxidation of organic aerosol particles is typically determined by measuring $\mathrm{O}: \mathrm{C}$ ratios (Aiken et al., 2008; Chhabra et al., 2011) or averaged carbon oxidation state (Kroll et al., 2011) when a high-resolution aerosol mass spectrometer is used. Alternatively, as discussed in Sect. 3.2, $f_{44}$ is used as a measure of oxidation of unit resolution mass spectral data. Increasing $f_{44}$ has been used to infer the presence of more oxygenated molecules and has therefore been expected to lead to increased particle hygroscopicity.

Figure 9 shows the relationship between the hygroscopicity ( $\left.\kappa_{\text {HTDMA }}\right)$ of particles of a single size and $f_{44}$ measured simultaneously by the ToF-AMS for each precursor at both high and low initial mixing ratios. The linear fit parameters and coefficient of determination $\left(r^{2}\right)$ for each selected particle size are listed in Table 5. As has previously been observed in various SOA systems (Massoli et al., 2010; Duplissy et al., 2011; Frosch et al., 2011), myrcene, linalool and, to a lesser extent, $\alpha$-pinene derived particle hygroscopicity correlate positively with $f_{44}$. In the cases of myrcene and linalool, the correlation sometimes weakens for the largest sizes towards the end of the experiments, when the growth factor stops increasing but $f_{44}$ continues to rise. There is not however strong correlation between the particle 
Table 5. Linear fit parameters and coefficient of determination $\left(R^{2}\right)$ of the relationship between the hygroscopicity (represented by $\kappa_{\mathrm{HTDMA}}$ ) of particles of a single size and the degree of particle oxidation (represented by $f_{44}$ ).

\begin{tabular}{|c|c|c|c|c|c|}
\hline Precursor & $\begin{array}{l}\text { Initial mixing } \\
\text { ratio }(\mathrm{ppbV})\end{array}$ & $\begin{array}{c}D_{0} \\
(\mathrm{~nm})\end{array}$ & $M$ & $C$ & $R^{2}$ \\
\hline$\alpha$-Pinene & 50 & 200 & $-0.142 \pm 0.099$ & $0.024 \pm 0.009$ & 0.40 \\
\hline \multirow{2}{*}{$\beta$-Caryophyllene } & 50 & $\begin{array}{l}200 \\
300\end{array}$ & $\begin{array}{r}-0.003 \pm 0.001 \\
0.068 \pm 0.052 \\
\end{array}$ & $\begin{array}{r}0.004 \pm 0.000 \\
-0.001 \pm 0.011\end{array}$ & $\begin{array}{l}0.87 \\
0.60\end{array}$ \\
\hline & 250 & $\begin{array}{l}250 \\
300\end{array}$ & $\begin{array}{l}-0.019 \pm 0.003 \\
-0.016 \pm 0.009\end{array}$ & $\begin{array}{r}-0.067 \pm 0.009 \\
0.055 \pm 0.025\end{array}$ & $\begin{array}{l}0.67 \\
0.10\end{array}$ \\
\hline \multirow{2}{*}{ Limonene } & 50 & $\begin{array}{l}200 \\
200\end{array}$ & $\begin{array}{l}0.044 \pm 0.034 \\
0.042 \pm 0.037\end{array}$ & $\begin{array}{l}-0.240 \pm 0.253 \\
-0.214 \pm 0.259\end{array}$ & $\begin{array}{l}0.10 \\
0.16 \\
\end{array}$ \\
\hline & 250 & $\begin{array}{l}350 \\
500\end{array}$ & $\begin{array}{l}0.168 \pm 0.084 \\
0.055 \pm 0.028\end{array}$ & $\begin{array}{l}-0.018 \pm 0.016 \\
-0.229 \pm 0.149\end{array}$ & $\begin{array}{l}0.06 \\
0.36\end{array}$ \\
\hline \multirow[t]{2}{*}{ Linalool } & 50 & $\begin{array}{l}100 \\
150 \\
200\end{array}$ & $\begin{array}{r}0.024 \pm 0.002 \\
0.017 \pm 0.001 \\
-0.006 \pm 0.007 \\
\end{array}$ & $\begin{array}{r}-0.032 \pm 0.008 \\
-0.008 \pm 0.005 \\
0.119 \pm 0.047\end{array}$ & $\begin{array}{l}0.93 \\
0.94 \\
0.12\end{array}$ \\
\hline & 250 & $\begin{array}{l}150 \\
200\end{array}$ & $\begin{array}{r}0.029 \pm 0.002 \\
0.027 \pm 0.0014\end{array}$ & $\begin{array}{l}-0.019 \pm 0.007 \\
-0.028 \pm 0.006\end{array}$ & $\begin{array}{l}0.94 \\
0.95\end{array}$ \\
\hline \multirow{2}{*}{ Myrcene } & 50 & $\begin{array}{l}100 \\
150 \\
250\end{array}$ & $\begin{array}{l}0.036 \pm 0.003 \\
0.034 \pm 0.001 \\
0.006 \pm 0.003\end{array}$ & $\begin{array}{r}-0.188 \pm 0.021 \\
-0.200 \pm 0.012 \\
0.025 \pm 0.032\end{array}$ & $\begin{array}{l}0.96 \\
0.97 \\
0.22\end{array}$ \\
\hline & 250 & $\begin{array}{l}150 \\
250 \\
350\end{array}$ & $\begin{array}{l}0.041 \pm 0.011 \\
0.025 \pm 0.001 \\
0.022 \pm 0.003\end{array}$ & $\begin{array}{l}-0.242 \pm 0.092 \\
-0.123 \pm 0.008 \\
-0.124 \pm 0.030\end{array}$ & $\begin{array}{l}0.57 \\
0.97 \\
0.74\end{array}$ \\
\hline
\end{tabular}

hygroscopicity in the $\beta$-caryophyllene experiments and $f_{44}$. In the $\beta$-caryophyllene experiment the change in particle hygroscopicity is smaller than the precision of the HTDMA measurement, while the change in $f_{44}$ is $0.3 \%$ (over the HTDMA measurement period), so a high correlation is not expected. In the limonene experiments the growth factor at each dry size tended to increase with time. In the $250 \mathrm{ppbV}$ limonene experiment, $\kappa_{\text {HTDMA }}$ and $f_{44}$ correlate once $f_{44}$ starts to increase; however overall correlation between the $\mathrm{GF}_{D 0}=350 \mathrm{~nm}$ is low due to the fact that $f_{44}$ drops continuously from the start of the experiment and only start to increase after $\sim 2.5 \mathrm{~h}$. In the $50 \mathrm{ppbV}$ experiment there is a relatively large amount of scatter in consecutive HTDMA measurements which may account for the low correlation.

Figure 10 shows mean $f_{44}( \pm 3$ s.d.) and the particle hygroscopicity derived from HTDMA (filled symbols) and CCNc (open symbols) of the largest selected particle size during the last hour of each experiment (generally within hours 4 to 6 , depending upon the experiment duration) for each precursor at high and low mixing ratio. The largest selected particle size is chosen such that $f_{44}$ (mass fraction) is the closest representation of the particles sampled by the HTDMA and CCNc (it should be remembered that the average hygroscopicity values derived from both the HTDMA and CCNc are weighted according to the number of particles sampled with a given value, but the $f_{44}$ averages are from AMS mass-based averages). Figure 10 aims to illustrate the relationship between the absolute fraction of $m / z 44$ and particle hygroscopicity independent of precursor. It is apparent that $\alpha$-pinene, limonene, linalool and myrcene are able to generate particles with similar hygroscopicity $(\kappa \sim 0.1)$ despite $f_{44}$ ranging from $\sim 4$ to $11 \%$. Th $\beta$-caryophyllene derived particles exhibit an order of magnitude lower $\kappa$ than the other systems after 4 to $6 \mathrm{~h}$ of photooxidation as well as the lowest $f_{44}(\sim 2.5 \%)$. These findings indicate that while the level of oxidation of particles is clearly an important factor in determining water uptake properties, as shown in Fig. 9, it is only so inasmuch as it controls solubility. Other factors such as surface tension, molecular weight, density, and particle phase play important roles in determining $\kappa$ values (Petters et al., 2009b; Poulain et al., 2010; Good et al., 2010c; Cappa et al., 2011; Tang et al., 2012). This is probably the main reason why correlations were observed for single precursor SOA systems (Fig. 9), but overall there appears to be no systematic relationship between water uptake properties and the extent of oxidation (Fig. 10). In the single precursor SOA experiments, fewer of these factors vary. For example, molecular weight or density changes less during ageing 
when compared to switching between precursors of different molecular weight (Varutbangkul et al., 2006; Petters et al., 2009a). It should be noted that the lack of a clear relationship between $\kappa_{\mathrm{CCN}}$ and $f_{44}$ or $\mathrm{O}: \mathrm{C}$ have been previously reported (Frosch et al., 2011; Tang et al., 2012).

A similar investigation of SOA hygroscopicity, represented by $\kappa$ and the averaged carbon oxidation state $\left(\overline{\mathrm{OS}_{\mathrm{C}}}\right)$ determined from the offline analysis is shown in Fig. 11. The $\overline{\mathrm{OS}_{\mathrm{C}}}$ values of the SOA ranged from -0.96 to -0.88 for $\beta$ caryophyllene, -0.67 to -0.47 for limonene and -0.69 for the single $\alpha$-pinene experiment. Similar to the $f_{44}$ analysis, $\beta$-caryophyllene SOA showed the lowest $\overline{\mathrm{OS}_{\mathrm{C}}}$ values, indicating it was the least oxidized aerosol. This is perhaps expected since the parent VOC is the least volatile and early generation oxidation products can partition to the condensed phase. Both the monoterpenes have higher $\overline{\mathrm{OS}_{\mathrm{C}}}$ values, with limonene higher than $\alpha$-pinene. This may be a result of further oxidation of the limonene double bond, giving more oxidised products. A mean kappa value for the largest sized particles over the final hour of the experiment was used since the filter samples represent an instantaneous snapshot at the end of the experiment. From the samples available from offline analyses of limited subset of the precursors, it might be tempting to try to look for a relationship between $\overline{\mathrm{OS}_{\mathrm{C}}}$ and hygroscopicity. The fallibility of this approach can be seen from the online analysis when including the linalool and myrcene SOA data points. A direct comparison of data in Figs. 8 and 9 could only be performed using the three overlapping SOA systems of $\beta$-caryophyllene, $\alpha$-pinene and limonene. Both off- and online analyses methods determined lower level of oxidation for the $\beta$-caryophyllene SOA compared to that of limonene and $\alpha$-pinene. It is noteworthy, however, that the $\overline{\mathrm{OS}_{\mathrm{C}}}$ value of $\alpha$-pinene SOA is lower than that of limonene, whilst the $f_{44}$ is higher, suggesting a difference in the use of online derived $f_{44}$ and offline determined $\overline{\mathrm{OS}_{\mathrm{C}}}$ values in determining the degree of oxidation of particles. Including online data for linalool and myrcene SOA systems in this analysis led to the conclusion that a relationship between $f_{44}\left(\overline{\mathrm{OS}_{\mathrm{C}}}\right)$ and hygroscopicity could not be established and generalised for the combined SOA systems in this study.

The apparent independence of $\kappa$ values derived from suband super-saturated measurements of SOA particles of their degree of oxidation determined using both online and offline methods do not necessarily suggest that water uptake and chemical composition are not related in reality. Instead, they suggest that $f_{44}$ and $\overline{\mathrm{OS}_{\mathrm{C}}}$ are not the only determinant composition-related factors controlling water uptake of SOA particles and that other factors such as solubility, surface tension, molecular weight, density and particle phase are likely to be playing important roles in controlling $\kappa$ values (Petters and Kreidenweis, 2008; Petters et al., 2009a, b; Poulain et al., 2010; Cappa et al., 2011; Tang et al., 2012). In addition, as stated above, in the water uptake measurements, the RH of the SOA sample is controlled but the lack of control of satu-

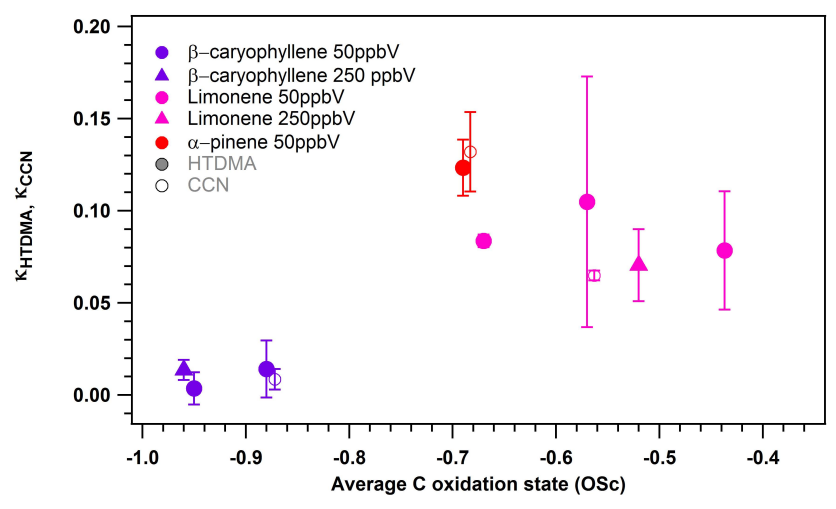

Fig. 11. $\kappa_{\text {HTDMA }}$ values average over the final hour for the largest measured size and $\kappa_{\mathrm{CCN}}$ of the appropriate experiments plotted against average $\mathrm{C}$ oxidation state calculated from SOA filter samples collected at the end of same experiments. The filled and open symbols are for HTDMA and CCN data, respectively. The $\kappa_{\mathrm{CCN}}$ data points have been offset very slightly to the right for display purpose.

ration ratio of any other semi-volatile component means they are free to evaporate during drying to initial size selection and to condense on humidification in determining their subsaturated growth or cloud activation potential. Sample treatment during online and offline chemical composition measurements are different. Particles sampled into the AMS were not actively dried. However, they were subjected to a supersonic expansion into the vacuum system, which could lead to freeze drying of water and semi-volatiles. The filter samples were collected over a relatively short period of time using a high flow rate of $3 \mathrm{~m}^{3} \mathrm{~min}^{-1}$ (i.e. in approximately $6 \mathrm{~min}$ ), and were stored at $-18^{\circ} \mathrm{C}$ almost immediately after collection. Such a protocol should minimise sampling artefacts of condensation and evaporation. Discrepancies between online measurements of composition and hygroscopic growth when particles contain substantial amounts of semi-volatile material show that correction for this fraction are required (Gysel et al., 2007), and the equilibration of semi-volatile material will likely contribute to discrepancies between measurements of chemical composition, sub-saturated hygroscopic growth and droplet activation in the laboratory (Good et al., 2010c) and atmosphere (Irwin et al., 2010).

\section{Conclusions}

Five structurally different biogenic VOCs were identified representing species emitted into the atmosphere with a range of chemical reactivity and complexity in their subsequent degradation. The studied compounds were $\alpha$-pinene, $\beta$ caryophyllene, limonene, linalool and myrcene. The chemical half-life for each of the compounds derived from their decay profiles appeared to be consistent with their published reactivity data towards the main oxidants of ozone 
and hydroxyl radical. The shortest lifetime (i.e. highest reactivity) was observed for $\beta$-caryophyllene, while the longest lifetime was found to be that of $\alpha$-pinene. The SOA particle formation profiles were found to be consistent with the derived VOC chemical lifetimes ( $\beta$-caryophyllene SOA peak number was the first to be reached, while $\alpha$-pinene SOA was the last). Investigations illustrated that SOA formation potential was higher when the same precursor is used at higher initial mixing ratio compared to a lower initial mixing ratio case.

The fractional contributions of mass fragments 43 and 44 to the total organic signal ( $f_{43}$ and $f_{44}$ ) were used to characterise the extent of oxidation of the SOA as measured online by an aerosol mass spectrometer. The $f_{43}$ and $f_{44}$ for the studied systems under lower and higher initial mixing ratios varied considerably, both in magnitude and temporal evolution. These results illustrated that SOA generated from a single biogenic precursor cannot and should not be used as a proxy for biogenic SOA in general. In addition, the values of $f_{44}$, which are widely used in the literature to indicate the level of oxygenation of organic aerosol in field and laboratory studies, are very much dependent on the type of precursor, the extent of photochemical ageing as well as on the initial experimental conditions.

Similarly, the generated SOA particles exhibited a range of hygroscopic properties, represented by $\kappa_{\text {HTDMA }}$, depending on the type of precursor, its initial mixing ratio and photochemical ageing. For example, the $\beta$-caryophyllene SOA particles were the least hygroscopic $\left(\kappa_{\text {HTDMA }} \sim 0.01\right)$, while $\alpha$-pinene, limonene, linalool and myrcene produced particles with higher hygroscopicity ( $\kappa \sim 0.03$ to 0.14$)$. Considering each selected dry size separately, there was a positive correlation between hygroscopicity ( $\left.\kappa_{\text {HTDMA }}\right)$ and time (i.e. degree of oxidation). This correlation was generally strong $\left(r^{2}>0.9\right)$ for limonene, linalool and myrcene SOA, whilst for the $\beta$ caryophyllene the change in $\kappa_{\text {HTDMA }}$ was small and could not be resolved within the measurement uncertainty (although correlation was observed). The increases of $\kappa_{\text {HTDMA }}$ with time indicated that SOA formed from molecules that partition from the gas phase later in the experiments were more hygroscopic. The $\mathrm{CCN}$ activity of the formed SOA particles, represented by $\kappa_{\mathrm{CCN}}$, showed no temporal trends for the lower mixing ratio cases. The two higher mixing ratio cases of linalool and myrcene, on the other hand, showed reduced $\mathrm{CCN}$ activity compared to their lower mixing ratio measurements. However, these conclusions were based on a significantly limited $\mathrm{CCNc}$ data set compared to other data sets. The average $\kappa$ values derived from the HTDMA and $\mathrm{CCNc}$ were generally found to cover the same range for each precursor both for the 50 and $250 \mathrm{ppbV}$ initial mixing ratios. The $\kappa_{\text {HTDMA }}$ values derived for $50 \mathrm{ppbV} \alpha$-pinene, linalool, and myrcene SOA appeared to be slightly lower than those derived from the $\mathrm{CCNc}$, especially during the first hours of the experiments. Given the lack of active control of semivolatile compound saturation ratios and the very different values likely to be experienced in each of the two instruments, as well as the role of factors such as molecular size, solubility and functional groups, the difference between the two $\kappa$ values is relatively small.

Consistent with previous studies, a positive correlation was found between the hygroscopicity of particles $\left(\kappa_{\text {HTDMA }}\right)$ of a single size and $f_{44}$ for myrcene, linalool and $\alpha$-pinene SOA (albeit the correlation for the latter was weaker). On the other hand, no such correlation was found for limonene SOA particles. Investigation of the generality of the relationship between $f_{44}$ and $\kappa_{\text {HTDMA }}$ revealed that $\alpha$-pinene, limonene, linalool and myrcene were all able to generate particles with similar hygroscopicity $\left(\kappa_{\text {HTDMA }} \sim 0.1\right)$ despite $f_{44}$ exhibiting a relatively wide range of values $(\sim 4$ to $11 \%)$. Similarly, $\kappa_{\mathrm{CCN}}$ was found to be independent of $f_{44}$. The same findings were also true when sub- and super-saturated water uptake properties of SOA were compared to the averaged carbon oxidation state $\left(\overline{\mathrm{OS}_{\mathrm{C}}}\right)$ determined offline. These results suggest that $\kappa$ values derived from sub- and super-saturated measurements of SOA particles are independent of their degree of oxidation, determined using both online and offline methods. These findings do not necessarily suggest that water uptake and chemical composition are not related in reality. Instead, they suggest that $f_{44}$ and $\overline{\mathrm{OS}_{\mathrm{C}}}$ are not the only determinant composition-related factors controlling water uptake of SOA particles and that other factors such as solubility, surface tension, molecular weight, density and particle phase are likely to be playing important roles in doing so. Additionally, the findings may emphasise the possible impact of the lack of control of saturation ratio of semi-volatile compounds in the current state-of-the-art techniques employed to determine the chemical composition and water uptake properties of aerosol particles.

Acknowledgements. The authors gratefully acknowledge the UK Natural Environment Research Council (NERC) for funding of the APPRAISE ACES (NE/E011217/1) and ACIDPRUF (NE/I020121/1) consortia. The authors would also like to acknowledge support from the EU-FP7 EUROCHAMP-2 project. M. R. Alfarra was supported by UK National Centre for Atmospheric Sciences (NCAS) funding.

Edited by: H. Su

\section{References}

Aiken, A. C., DeCarlo, P. F., Kroll, J. H., Worsnop, D. R., Huffman, J. A., Docherty, K. S., Ulbrich, I. M., Mohr, C., Kimmel, J. R., Sueper, D., Sun, Y., Zhang, Q., Trimborn, A., Northway, M., Ziemann, P. J., Canagaratna, M. R., Onasch, T. B., Alfarra, M. R., Prevot, A. S. H., Dommen, J., Duplissy, J., Metzger, A., Baltensperger, U., and Jimenez, J. L.: O/C and OM/OC Ratios of Primary, Secondary, and Ambient Organic Aerosols with HighResolution Time-of-Flight Aerosol Mass Spectrometry, Environ. Sci. Technol., 42, 4478-4485, doi:10.1021/es703009q, 2008. 
Alfarra, M. R.: Insights into atmospheric organic aerosols using an aerosol mass spectrometer, $\mathrm{PhD}$ Thesis, Chemical Engineering Department, University of Manchester Institute of Science and Technology (UMIST), UK, 2004.

Alfarra, M. R., Coe, H., Allan, J. D., Bower, K. N., Boudries, H., Canagaratna, M. R., Jimenez, J. L., Jayne, J. T., Garforth, A., Li, S.-M., and Worsnop, D. R.: Characterization of urban and rural organic particulate in the Lower Fraser Valley using two Aerodyne aerosol mass spectrometers, Atmos. Environ., 38, 57455758, 2004.

Alfarra, M. R., Paulsen, D., Gysel, M., Garforth, A. A., Dommen, J., Prév^t, A. S. H., Worsnop, D. R., Baltensperger, U., and Coe, H.: A mass spectrometric study of secondary organic aerosols formed from the photooxidation of anthropogenic and biogenic precursors in a reaction chamber, Atmos. Chem. Phys., 6, 52795293, doi:10.5194/acp-6-5279-2006, 2006.

Alfarra, M. R., Hamilton, J. F., Wyche, K. P., Good, N., Ward, M. W., Carr, T., Barley, M. H., Monks, P. S., Jenkin, M. E., Lewis, A. C., and McFiggans, G. B.: The effect of photochemical ageing and initial precursor concentration on the composition and hygroscopic properties of $\beta$-caryophyllene secondary organic aerosol, Atmos. Chem. Phys., 12, 6417-6436, doi:10.5194/acp12-6417-2012, 2012.

Allan, J. D., Alfarra, M. R., Bower, K. N., Coe, H., Jayne, J. T., Worsnop, D. R., Aalto, P. P., Kulmala, M., Hyötyläinen, T., Cavalli, F., and Laaksonen, A.: Size and composition measurements of background aerosol and new particle growth in a Finnish forest during QUEST 2 using an Aerodyne Aerosol Mass Spectrometer, Atmos. Chem. Phys., 6, 315-327, doi:10.5194/acp-6-315-2006, 2006.

Asa-Awuku, A., Engelhart, G. J., Lee, B. H., Pandis, S. N., and Nenes, A.: Relating CCN activity, volatility, and droplet growth kinetics of $\beta$-caryophyllene secondary organic aerosol, Atmos. Chem. Phys., 9, 795-812, doi:10.5194/acp-9-795-2009, 2009.

Atkinson, R. and Arey, J.: Gas-phase tropospheric chemistry of biogenic volatile organic compounds: a review, Atmos. Environ., 37, 197-219, 2003.

Bateman, A. P., Nizkorodov, S. A., Laskin, J., and Laskin, A.: High-Resolution Electrospray Ionization Mass Spectrometry Analysis of Water-Soluble Organic Aerosols Collected with a Particle into Liquid Sampler, Anal. Chem., 82, 8010-8016, doi:10.1021/ac1014386, 2010.

Boissard, C., Cao, X. L., Juan, C. Y., Hewitt, C. N., and Gallagher, M.: Seasonal variations in VOC emission rates from gorse (Ulex europaeus), Atmos. Environ., 35, 917-927, doi:10.1016/S13522310(00)00362-9, 2001

Canagaratna, M. R., Jayne, J. T., Jimenez, J. L., Allan, J. D., Alfarra, M. R., Zhang, Q., Onasch, T. B., Drewnick, F., Coe, H., Middlebrook, A., Delia, A., Williams, L. R., Trimborn, A. M., Northway, M. J., DeCarlo, P. F., Kolb, C. E., Davidovits, P., and Worsnop, D. R.: Chemical and microphysical characterization of ambient aerosols with the aerodyne aerosol mass spectrometer, Mass Spectrom. Rev., 26, 185-222, 2007.

Cappa, C. D., Che, D. L., Kessler, S. H., Kroll, J. H., and Wilson, K. R.: Variations in organic aerosol optical and hygroscopic properties upon heterogeneous OH oxidation, J. Geophys. Res.-Atmos., 116, D15204, doi:10.1029/2011jd015918, 2011.

Carlton, A. G., Wiedinmyer, C., and Kroll, J. H.: A review of Secondary Organic Aerosol (SOA) formation from isoprene, At- mos. Chem. Phys., 9, 4987-5005, doi:10.5194/acp-9-4987-2009, 2009.

Chan, A. W. H., Kroll, J. H., Ng, N. L., and Seinfeld, J. H.: Kinetic modeling of secondary organic aerosol formation: effects of particle- and gas-phase reactions of semivolatile products, Atmos. Chem. Phys., 7, 4135-4147, doi:10.5194/acp-7-4135-2007, 2007.

Chhabra, P. S., Ng, N. L., Canagaratna, M. R., Corrigan, A. L., Russell, L. M., Worsnop, D. R., Flagan, R. C., and Seinfeld, J. H.: Elemental composition and oxidation of chamber organic aerosol, Atmos. Chem. Phys., 11, 8827-8845, doi:10.5194/acp-11-88272011, 2011.

Cottrell, L. D., Griffin, R. J., Jimenez, J. L., Zhang, Q., Ulbrich, I., Ziemba, L. D., Beckman, P. J., Sive, B. C., and Talbot, R. W.: Submicron particles at Thompson Farm during ICARTT measured using aerosol mass spectrometry, J. Geophys. Res., 113, D08212, doi:10.1029/2007jd009192, 2008.

Cubison, M. J., Alfarra, M. R., Allan, J., Bower, K. N., Coe, H., McFiggans, G. B., Whitehead, J. D., Williams, P. I., Zhang, Q., Jimenez, J. L., Hopkins, J., and Lee, J.: The characterisation of pollution aerosol in a changing photochemical environment, Atmos. Chem. Phys., 6, 5573-5588, doi:10.5194/acp-6-5573-2006, 2006.

de Gouw, J. A., Middlebrook, A. M., Warneke, C., Goldan, P. D., Kuster, W. C., Roberts, J. M., Fehsenfeld, F. C., Worsnop, D. R., Canagaratna, M. R., Pszenny, A. A. P., Keene, W. C., Marchewka, M., Bertman, S. B., and Bates, T. S.: Budget of organic carbon in a polluted atmosphere: Results from the New England Air Quality Study in 2002, J. Geophys. Res.-Atmos., 110, D16305, doi:10.1029/2004jd005623, 2005.

Dommen, J., Metzger, A., Duplissy, J., Kalberer, M., Alfarra, M. R., Gascho, A., Weingartner, E., Prevot, A. S. H., Verheggen, B., and Baltensperger, U.: Laboratory observation of oligomers in the aerosol from isoprene/ $\mathrm{NO}_{\mathrm{x}}$ photooxidation, Geophys. Res. Lett., 33, L13805, doi:10.1029/2006gl026523, 2006.

Dommen, J., Hellen, H., Saurer, M., Jaeggi, M., Siegwolf, R., Metzger, A., Duplissy, J., Fierz, M., and Baltensperger, U.: Determination of the Aerosol Yield of Isoprene in the Presence of an Organic Seed with Carbon Isotope Analysis, Environ. Sci. Technol., 43, 6697-6702, 2009.

Donahue, N. M., Epstein, S. A., Pandis, S. N., and Robinson, A. L.: A two-dimensional volatility basis set: 1. organic-aerosol mixing thermodynamics, Atmos. Chem. Phys., 11, 3303-3318, doi:10.5194/acp-11-3303-2011, 2011.

Drewnick, F., Hings, S. S., DeCarlo, P., Jayne, J. T., Gonin, M., Fuhrer, K., Weimer, S., Jimenez, J. L., Demerjian, K. L., Borrmann, S., and Worsnop, D. R.: A new time-of-flight aerosol mass spectrometer (TOF-AMS) - Instrument description and first field deployment, Aerosol Sci. Tech., 39, 637-658, 2005.

Duplissy, J., Gysel, M., Alfarra, M. R., Dommen, J., Metzger, A., Prevot, A. S. H., Weingartner, E., Laaksonen, A., Raatikainen, T., Good, N., Turner, F., McFiggans, G., and Baltensperger, U.: Cloud forming potential of secondary organic aerosol under near atmospheric conditions, Geophys. Res. Lett., 35, L03818, doi:10.1029/2007gl031075, 2008.

Duplissy, J., DeCarlo, P. F., Dommen, J., Alfarra, M. R., Metzger, A., Barmpadimos, I., Prevot, A. S. H., Weingartner, E. Tritscher, T., Gysel, M., Aiken, A. C., Jimenez, J. L., Canagaratna, M. R., Worsnop, D. R., Collins, D. R., Tomlinson, J., 
and Baltensperger, U.: Relating hygroscopicity and composition of organic aerosol particulate matter, Atmos. Chem. Phys., 11, 1155-1165, doi:10.5194/acp-11-1155-2011, 2011.

Forstner, H. J. L., Flagan, R. C., and Seinfeld, J. H.: Secondary organic aerosol from the photoxidation of aromatic hydrocarbons: molecular composition, Environ. Sci. Tech., 31, 13451358, 1997.

Frosch, M., Bilde, M., DeCarlo, P. F., Jurányi, Z., Tritscher, T., Dommen, J., Donahue, N. M., Gysel, M., Weingartner, E., and Baltensperger, U.: Relating cloud condensation nuclei activity and oxidation level of $\alpha$-pinene secondary organic aerosols, J. Geophys. Res.-Atmos., 116, D22212, doi:10.1029/2011jd016401, 2011.

Frosch, M., Bilde, M., Nenes, A., Praplan, A. P., Jurányi, Z., Dommen, J., Gysel, M., Weingartner, E., and Baltensperger, U.: CCN activity and volatility of $\beta$-caryophyllene secondary organic aerosol, Atmos. Chem. Phys., 13, 2283-2297, doi:10.5194/acp13-2283-2013, 2013.

Glasius, M., Lahaniati, M., Calogirou, A., Bella, D. D., Jensen, N. R., Hjorth, J., Kotzias, D., and Larsen, B. R.: Carboxylic acids in secondary aerosol from oxidation of cyclic monoterpenes by ozone, Environ. Sci. Technol., 34, 1001-1010, 2000.

Goldstein, A. H. and Galbally, I. E.: Known and unexplored organic constituents in the earth's atmosphere, Environ. Sci. Technol., 41, 1514-1521, 2007.

Good, N., Coe, H., and McFiggans, G.: Instrumentational operation and analytical methodology for the reconciliation of aerosol water uptake under sub- and supersaturated conditions, Atmos. Meas. Tech., 3, 1241-1254, doi:10.5194/amt-3-1241-2010, 2010a.

Good, N., Topping, D. O., Allan, J. D., Flynn, M., Fuentes, E., Irwin, M., Williams, P. I., Coe, H., and McFiggans, G.: Consistency between parameterisations of aerosol hygroscopicity and CCN activity during the RHaMBLe discovery cruise, Atmos. Chem. Phys., 10, 3189-3203, doi:10.5194/acp-10-3189-2010, $2010 b$

Good, N., Topping, D. O., Duplissy, J., Gysel, M., Meyer, N. K., Metzger, A., Turner, S. F., Baltensperger, U., Ristovski, Z., Weingartner, E., Coe, H., and McFiggans, G.: Widening the gap between measurement and modelling of secondary organic aerosol properties?, Atmos. Chem. Phys., 10, 2577-2593, doi:10.5194/acp-10-2577-2010, 2010c.

Griffin, R. J., Cocker, D. R., III, Flagan, R. C., and Seinfeld, J. H.: Organic aerosol formation from the oxidation of biogenic hydrocarbons, J. Geophys. Res., 104, 3555-3567, 1999.

Gysel, M., Crosier, J., Topping, D. O., Whitehead, J. D., Bower, K. N., Cubison, M. J., Williams, P. I., Flynn, M. J., McFiggans, G. B., and Coe, H.: Closure study between chemical composition and hygroscopic growth of aerosol particles during TORCH2, Atmos. Chem. Phys., 7, 6131-6144, doi:10.5194/acp-7-61312007, 2007.

Gysel, M., McFiggans, G. B., and Coe, H.: Inversion of tandem differential mobility analyser (TDMA) measurements, J. Aerosol Sci., 40, 134-151, 2009.

Hallquist, M., Wenger, J. C., Baltensperger, U., Rudich, Y., Simpson, D., Claeys, M., Dommen, J., Donahue, N. M., George, C., Goldstein, A. H., Hamilton, J. F., Herrmann, H., Hoffmann, T., Iinuma, Y., Jang, M., Jenkin, M. E., Jimenez, J. L., Kiendler-Scharr, A., Maenhaut, W., McFiggans, G., Mentel, Th.
F., Monod, A., Prévôt, A. S. H., Seinfeld, J. H., Surratt, J. D., Szmigielski, R., and Wildt, J.: The formation, properties and impact of secondary organic aerosol: current and emerging issues, Atmos. Chem. Phys., 9, 5155-5236, doi:10.5194/acp-9-51552009, 2009.

Hamilton, J. F., Rami Alfarra, M., Wyche, K. P., Ward, M. W., Lewis, A. C., McFiggans, G. B., Good, N., Monks, P. S., Carr, T., White, I. R., and Purvis, R. M.: Investigating the use of secondary organic aerosol as seed particles in simulation chamber experiments, Atmos. Chem. Phys., 11, 5917-5929, doi:10.5194/acp11-5917-2011, 2011.

He, C., Murray, F., and Lyons, T.: Monoterpene and isoprene emissions from 15 Eucalyptus species in Australia, Atmos. Environ., 34, 645-655, doi:10.1016/S1352-2310(99)00219-8, 2000.

Hildebrandt, L., Donahue, N. M., and Pandis, S. N.: High formation of secondary organic aerosol from the photo-oxidation of toluene, Atmos. Chem. Phys., 9, 2973-2986, doi:10.5194/acp-92973-2009, 2009.

Irwin, M., Good, N., Crosier, J., Choularton, T. W., and McFiggans, G.: Reconciliation of measurements of hygroscopic growth and critical supersaturation of aerosol particles in central Germany, Atmos. Chem. Phys., 10, 11737-11752, doi:10.5194/acp10-11737-2010, 2010.

Jang, M., and Kamens, R. M.: Characterization of secondary aerosol from the photooxidation of toluene in the presence of $\mathrm{NO}_{\mathrm{x}}$ and 1-propene, Environ. Sci. Technol., 35, 3626-3639, 2001.

Jaoui, M. and Kamens, R. M.: Gaseous and particulate oxidation products analysis of a mixture of a-pinene + b-pinene $/ \mathrm{O}_{3} / \mathrm{air}$ in the absence of light and a-pinene $+\mathrm{b}$-pinene/ $/ \mathrm{NO}_{\mathrm{x}} /$ air in the presence of natural sunlight, J. Atmos. Chem., 44, 259-297, 2003.

Jaoui, M., Leungsakul, S., and Kamens, R. M.: Gas and particle products distribution from the reaction of beta-caryophyllene with ozone, J. Atmos. Chem., 45, 261-287, 2003.

Jenkin, M. E., Wyche, K. P., Evans, C. J., Carr, T., Monks, P. S., Alfarra, M. R., Barley, M. H., McFiggans, G. B., Young, J. C., and Rickard, A. R.: Development and chamber evaluation of the MCM v3.2 degradation scheme for $\beta$-caryophyllene, Atmos. Chem. Phys., 12, 5275-5308, doi:10.5194/acp-12-52752012, 2012.

Jimenez, J. L., Canagaratna, M. R., Donahue, N. M., Prevot, A. S. H., Zhang, Q., Kroll, J. H., DeCarlo, P. F., Allan, J. D., Coe, H., Ng, N. L., Aiken, A. C., Docherty, K. S., Ulbrich, I. M., Grieshop, A. P., Robinson, A. L., Duplissy, J., Smith, J. D., Wilson, K. R., Lanz, V. A., Hueglin, C., Sun, Y. L., Tian, J., Laaksonen, A., Raatikainen, T., Rautiainen, J., Vaattovaara, P., Ehn, M., Kulmala, M., Tomlinson, J. M., Collins, D. R., Cubison, M. J., E, Dunlea, J., Huffman, J. A., Onasch, T. B., Alfarra, M. R., Williams, P. I., Bower, K., Kondo, Y., Schneider, J., Drewnick, F., Borrmann, S., Weimer, S., Demerjian, K., Salcedo, D., Cottrell, L., Griffin, R., Takami, A., Miyoshi, T., Hatakeyama, S., Shimono, A., Sun, J. Y., Zhang, Y. M., Dzepina, K., Kimmel, J. R., Sueper, D., Jayne, J. T., Herndon, S. C., Trimborn, A. M., Williams, L. R., Wood, E. C., Middlebrook, A. M., Kolb, C. E., Baltensperger, U., and Worsnop, D. R.: Evolution of Organic Aerosols in the Atmosphere, Science, 326, 1525-1529, doi:10.1126/science.1180353, 2009.

Juranyi, Z., Gysel, M., Duplissy, J., Weingartner, E., Tritscher, T., Dommen, J., Henning, S., Ziese, M., Kiselev, A., Stratmann, F., George, I., and Baltensperger, U.: Influence of gas-to-particle 
partitioning on the hygroscopic and droplet activation behaviour of [small alpha]-pinene secondary organic aerosol, Phys. Chem. Chem. Phys., 11, 8091-8097, doi:10.1039/b904162a, 2009.

Kanakidou, M., Seinfeld, J. H., Pandis, S. N., Barnes, I., Dentener, F. J., Facchini, M. C., Van Dingenen, R., Ervens, B., Nenes, A., Nielsen, C. J., Swietlicki, E., Putaud, J. P., Balkanski, Y., Fuzzi, S., Horth, J., Moortgat, G. K., Winterhalter, R., Myhre, C. E. L., Tsigaridis, K., Vignati, E., Stephanou, E. G., and Wilson, J.: Organic aerosol and global climate modelling: a review, Atmos. Chem. Phys., 5, 1053-1123, doi:10.5194/acp-5-1053-2005, 2005.

King, S. M., Rosenoern, T., Shilling, J. E., Chen, Q., and Martin, S. T.: Increased cloud activation potential of secondary organic aerosol for atmospheric mass loadings, Atmos. Chem. Phys., 9, 2959-2971, doi:10.5194/acp-9-2959-2009, 2009.

Kleindienst, T. E., Conver, T. S., McIver, C. D., and Edney, E. O.: Determination of secondary organic aerosol products from the photooxidation of toluene and their implications in ambient $\mathrm{PM}_{2.5}$, J. Atmos. Chem., 47, 79-100, 2004.

Kroll, J. H. and Seinfeld, J. H.: Chemistry of secondary organic aerosol: Formation and evolution of low-volatility organics in the atmosphere, Atmos. Environ., 42, 3593-3624, 2008.

Kroll, J. H., Ng, N. L., Murphy, S. M., Flagan, R. C., and Seinfeld, J. H.: Secondary Organic Aerosol Formation from Isoprene Photooxidation, Environ. Sci. Technol., 40, 1869-1877, doi:10.1021/es0524301, 2006.

Kroll, J. H., Donahue, N. M., Jimenez, J. L., Kessler, S. H., Canagaratna, M. R., Wilson, K. R., Altieri, K. E., Mazzoleni, L. R., Wozniak, A. S., Bluhm, H., Mysak, E. R., Smith, J. D., Kolb, C. E., and Worsnop, D. R.: Carbon oxidation state as a metric for describing the chemistry of atmospheric organic aerosol, Nat. Chem., 3, 133-139, 2011.

Lambe, A. T., Onasch, T. B., Massoli, P., Croasdale, D. R., Wright, J. P., Ahern, A. T., Williams, L. R., Worsnop, D. R., Brune, W. H., and Davidovits, P.: Laboratory studies of the chemical composition and cloud condensation nuclei $(\mathrm{CCN})$ activity of secondary organic aerosol (SOA) and oxidized primary organic aerosol (OPOA), Atmos. Chem. Phys., 11, 8913-8928, doi:10.5194/acp11-8913-2011, 2011.

Lanz, V. A., Alfarra, M. R., Baltensperger, U., Buchmann, B., Hueglin, C., and Prévôt, A. S. H.: Source apportionment of submicron organic aerosols at an urban site by factor analytical modelling of aerosol mass spectra, Atmos. Chem. Phys., 7, 15031522, doi:10.5194/acp-7-1503-2007, 2007.

Lee, A., Goldstein, A. H., Keywood, M. D., Gao, S., Varutbangkul, V., Bahreini, R., Ng, N. L., Flagan, R. C., and Seinfeld, J. H.: Gas-phase products and secondary aerosol yields from the ozonolysis of ten different terpenes, J. Geophys. Res., 111, D07302, doi:10.1029/2005jd006437, 2006a.

Lee, A., Goldstein, A. H., Kroll, J. H., Ng, N. L., Varutbangkul, V., Flagan, R. C., and Seinfeld, J. H.: Gas-phase products and secondary aerosol yields from the photooxidation of 16 different terpenes, J. Geophys. Res., 111, D17305, doi:10.1029/2006jd007050, 2006 b.

Li, Y. J., Chen, Q., Guzman, M. I., Chan, C. K., and Martin, S. T.: Second-generation products contribute substantially to the particle-phase organic material produced by $\beta$-caryophyllene ozonolysis, Atmos. Chem. Phys., 11, 121-132, doi:10.5194/acp11-121-2011, 2011.
Massling, A., Niedermeier, N., Hennig, T., Fors, E. O., Swietlicki, E., Ehn, M., Hämeri, K., Villani, P., Laj, P., Good, N., McFiggans, G., and Wiedensohler, A.: Results and recommendations from an intercomparison of six Hygroscopicity-TDMA systems, Atmos. Meas. Tech., 4, 485-497, doi:10.5194/amt-4-485-2011, 2011.

Massoli, P., Lambe, A. T., Ahern, A. T., Williams, L. R., Ehn, M., Mikkilä, J., Canagaratna, M. R., Brune, W. H., Onasch, T. B., Jayne, J. T., Petäjä, T., Kulmala, M., Laaksonen, A., Kolb, C. E., Davidovits, P., and Worsnop, D. R.: Relationship between aerosol oxidation level and hygroscopic properties of laboratory generated secondary organic aerosol (SOA) particles, Geophys. Res. Lett., 37, L24801, doi:10.1029/2010g1045258, 2010.

Matsunaga, A. and Ziemann, P. J.: Gas-Wall Partitioning of Organic Compounds in a Teflon Film Chamber and Potential Effects on Reaction Product and Aerosol Yield Measurements, Aerosol Sci. Tech., 44, 881-892, 2010.

Meyer, N. K., Duplissy, J., Gysel, M., Metzger, A., Dommen, J., Weingartner, E., Alfarra, M. R., Prevot, A. S. H., Fletcher, C., Good, N., McFiggans, G., Jonsson, Å. M., Hallquist, M., Baltensperger, U., and Ristovski, Z. D.: Analysis of the hygroscopic and volatile properties of ammonium sulphate seeded and unseeded SOA particles, Atmos. Chem. Phys., 9, 721-732, doi:10.5194/acp-9-721-2009, 2009.

Ng, N. L., Kroll, J. H., Keywood, M. D., Bahreini, R., Varutbangkul, V., Flagan, R. C., Seinfeld, J. H., Lee, A., and Goldstein, A. H.: Contribution of first- versus second-generation products to secondary organic aerosols formed in the oxidation of biogenic hydrocarbons, Environ. Sci. Technol., 40, 2283-2297, 2006.

Ng, N. L., Kroll, J. H., Chan, A. W. H., Chhabra, P. S., Flagan, R. C., and Seinfeld, J. H.: Secondary organic aerosol formation from $m$-xylene, toluene, and benzene, Atmos. Chem. Phys., 7, 3909-3922, doi:10.5194/acp-7-3909-2007, 2007.

Ng, N. L., Canagaratna, M. R., Zhang, Q., Jimenez, J. L., Tian, J., Ulbrich, I. M., Kroll, J. H., Docherty, K. S., Chhabra, P. S., Bahreini, R., Murphy, S. M., Seinfeld, J. H., Hildebrandt, L., Donahue, N. M., DeCarlo, P. F., Lanz, V. A., Prévôt, A. S. H., Dinar, E., Rudich, Y., and Worsnop, D. R.: Organic aerosol components observed in Northern Hemispheric datasets from Aerosol Mass Spectrometry, Atmos. Chem. Phys., 10, 46254641, doi:10.5194/acp-10-4625-2010, 2010.

Odum, J. R., Hoffmann, T., Bowman, F., Collins, D., Flagan, R. C., and Seinfeld, J. H.: Gas/particle partitioning and secondary organic aerosol yields, Environ. Sci. Technol., 30, 2580-2585, 1996.

Owen, S. M., Boissard, C., and Hewitt, C. N.: Volatile organic compounds (VOCs) emitted from 40 Mediterranean plant species: VOC speciation and extrapolation to habitat scale, Atmos. Environ., 35, 5393-5409, doi:10.1016/S1352-2310(01)00302-8, 2001.

Pandis, S. N., Harley, R. H., Cass, G. R., and Seinfeld, J. H.: Secondary organic aerosol formation and transport, Atmos. Environ., 26A, 2269-2282, 1992.

Pankow, J. F.: An absorption model of the gas/aerosol partitioning involved in the formation of secondary organic aerosol, Atmos. Environ., 28, 189-194, 1994.

Petters, M. D. and Kreidenweis, S. M.: A single parameter representation of hygroscopic growth and cloud condensation nucleus 
activity, Atmos. Chem. Phys., 7, 1961-1971, doi:10.5194/acp-71961-2007, 2007.

Petters, M. D. and Kreidenweis, S. M.: A single parameter representation of hygroscopic growth and cloud condensation nucleus activity - Part 2: Including solubility, Atmos. Chem. Phys., 8, 6273-6279, doi:10.5194/acp-8-6273-2008, 2008.

Petters, M. D., Kreidenweis, S. M., Prenni, A. J., Sullivan, R. C., Carrico, C. M., Koehler, K. A., and Ziemann, P. J.: Role of molecular size in cloud droplet activation, Geophys. Res. Lett., 36, L22801, doi:10.1029/2009g1040131, 2009a.

Petters, M. D., Wex, H., Carrico, C. M., Hallbauer, E., Massling, A., McMeeking, G. R., Poulain, L., Wu, Z., Kreidenweis, S. M., and Stratmann, F.: Towards closing the gap between hygroscopic growth and activation for secondary organic aerosol - Part 2: Theoretical approaches, Atmos. Chem. Phys., 9, 3999-4009, doi:10.5194/acp-9-3999-2009, 2009b.

Pfaffenberger, L., Barmet, P., Slowik, J. G., Praplan, A. P., Dommen, J., Prévôt, A. S. H., and Baltensperger, U.: The link between organic aerosol mass loading and degree of oxygenation: an $\alpha$ pinene photooxidation study, Atmos. Chem. Phys., 13, 64936506, doi:10.5194/acp-13-6493-2013, 2013.

Poulain, L., Wu, Z., Petters, M. D., Wex, H., Hallbauer, E., Wehner, B., Massling, A., Kreidenweis, S. M., and Stratmann, F.: Towards closing the gap between hygroscopic growth and $\mathrm{CCN}$ activation for secondary organic aerosols - Part 3: Influence of the chemical composition on the hygroscopic properties and volatile fractions of aerosols, Atmos. Chem. Phys., 10, 37753785, doi:10.5194/acp-10-3775-2010, 2010.

Prenni, A. J., Petters, M. D., Kreidenweis, S. M., DeMott, P. J., and Ziemann, P. J.: Cloud droplet activation of secondary organic aerosol, J. Geophys. Res.-Atmos., 112, D10223, doi:10.1029/2006jd007963, 2007.

Presto, A. A., HuffHartz, K. E., and Donahue, N. M.: Secondary Organic Aerosol Production from Terpene Ozonolysis. 2. Effect of $\mathrm{NO}_{\mathrm{x}}$ Concentration, Environ. Sci. Technol., 39, 7046-7054, 2005a.

Presto, A. A., HuffHartz, K. E., and Donahue, N. M.: Secondary Organic Aerosol Production from Terpene Ozonolysis. 1. Effect of UV Radiation, Environ. Sci. Technol., 39, 7036-7045, $2005 \mathrm{~b}$.

Raatikainen, T., Vaattovaara, P., Tiitta, P., Miettinen, P., Rautiainen, J., Ehn, M., Kulmala, M., Laaksonen, A., and Worsnop, D. R.: Physicochemical properties and origin of organic groups detected in boreal forest using an aerosol mass spectrometer, Atmos. Chem. Phys., 10, 2063-2077, doi:10.5194/acp-10-20632010, 2010.

Roberts, G. C. and Nenes, A.: A Continuous-Flow Streamwise Thermal-Gradient CCN Chamber for Atmospheric Measurements, Aerosol Sci. Technol., 39, 206-221, 2005.

Robinson, A. L., Donahue, N. M., Shrivastava, M. K., Weitkamp, E. A., Sage, A. M., Grieshop, A. P., Lane, T. E., Pierce, J. R., and Pandis, S. N.: Rethinking organic aerosols: semivolatile emissions and photochemical aging, Science, 315, 1259-1262, doi:10.1126/science.1133061, 2007.

Seinfeld, J. H. and Pankow, J. F.: Organic atmospheric particulate material, Annu. Rev. Phys. Chem., 54, 121-140, 2003.

Shilling, J. E., Chen, Q., King, S. M., Rosenoern, T., Kroll, J. H., Worsnop, D. R., McKinney, K. A., and Martin, S. T.: Particle mass yield in secondary organic aerosol formed by the dark ozonolysis of $\alpha$-pinene, Atmos. Chem. Phys., 8, 2073-2088, doi:10.5194/acp-8-2073-2008, 2008.

Shilling, J. E., Chen, Q., King, S. M., Rosenoern, T., Kroll, J. H., Worsnop, D. R., DeCarlo, P. F., Aiken, A. C., Sueper, D., Jimenez, J. L., and Martin, S. T.: Loading-dependent elemental composition of $\alpha$-pinene SOA particles, Atmos. Chem. Phys., 9, 771-782, doi:10.5194/acp-9-771-2009, 2009.

Slowik, J. G., Stroud, C., Bottenheim, J. W., Brickell, P. C., Chang, R. Y.-W., Liggio, J., Makar, P. A., Martin, R. V., Moran, M. D., Shantz, N. C., Sjostedt, S. J., van Donkelaar, A., Vlasenko, A., Wiebe, H. A., Xia, A. G., Zhang, J., Leaitch, W. R., and Abbatt, J. P. D.: Characterization of a large biogenic secondary organic aerosol event from eastern Canadian forests, Atmos. Chem. Phys., 10, 2825-2845, doi:10.5194/acp-10-2825-2010, 2010.

Spanke, J., Rannik, Ü., Forkel, R., Nigge, W., and Hoffmann, T.: Emission fluxes and atmospheric degradation of monoterpenes above a boreal forest: field measurements and modelling, Tellus B, 53, 406-422, doi:10.1034/j.1600-0889.2001.530407.x, 2001.

Swietlicki, E., Hansson, H. C., Hameri, K., Svenningsson, B., Massling, A., McFiggans, G., McMurry, P. H., Petaja, T., Tunved, P., Gysel, M., Topping, D., Weingartner, E., Baltensperger, U., Rissler, J., Wiedensohler, A., and Kulmala, M.: Hygroscopic properties of submicrometer atmospheric aerosol particles measured with H-TDMA instruments in various environments - a review, Tellus B, 60, 432-469, doi:10.1111/j.16000889.2008.00350.x, 2008.

Takegawa, N., Miyakawa, T., Kawamura, K., and Kondo, Y.: Contribution of Selected Dicarboxylic and \&ohgr;-Oxocarboxylic Acids in Ambient Aerosol to the $m / z 44$ Signal of an Aerodyne Aerosol Mass Spectrometer, Aerosol Sci. Tech., 41, 418-437, 2007.

Tang, X., Cocker III, D. R., and Asa-Awuku, A.: Are sesquiterpenes a good source of secondary organic cloud condensation nuclei (CCN)? Revisiting $\beta$-caryophyllene CCN, Atmos. Chem. Phys., 12, 8377-8388, doi:10.5194/acp-12-8377-2012, 2012.

Topping, D. O. and McFiggans, G.: Tight coupling of particle size, number and composition in atmospheric cloud droplet activation, Atmos. Chem. Phys., 12, 3253-3260, doi:10.5194/acp-12-32532012, 2012.

Tritscher, T., Dommen, J., DeCarlo, P. F., Gysel, M., Barmet, P. B., Praplan, A. P., Weingartner, E., Prévôt, A. S. H., Riipinen, I., Donahue, N. M., and Baltensperger, U.: Volatility and hygroscopicity of aging secondary organic aerosol in a smog chamber, Atmos. Chem. Phys., 11, 11477-11496, doi:10.5194/acp-1111477-2011, 2011.

VanReken, T. M., Ng, N. L., Flagan, R. C., and Seinfeld, J. H.: Cloud condensation nucleus activation properties of biogenic secondary organic aerosol, J. Geophys. Res.-Atmos., 110, D07206, doi:10.1029/2004jd005465, 2005.

Varutbangkul, V., Brechtel, F. J., Bahreini, R., Ng, N. L., Keywood, M. D., Kroll, J. H., Flagan, R. C., Seinfeld, J. H., Lee, A., and Goldstein, A. H.: Hygroscopicity of secondary organic aerosols formed by oxidation of cycloalkenes, monoterpenes, sesquiterpenes, and related compounds, Atmos. Chem. Phys., 6, $2367-$ 2388, doi:10.5194/acp-6-2367-2006, 2006.

Wex, H., Petters, M. D., Carrico, C. M., Hallbauer, E., Massling, A., McMeeking, G. R., Poulain, L., Wu, Z., Kreidenweis, S. M., and Stratmann, F.: Towards closing the gap between hygroscopic growth and activation for secondary organic aerosol: Part 1 - 
Evidence from measurements, Atmos. Chem. Phys., 9, 39873997, doi:10.5194/acp-9-3987-2009, 2009.

Williams, B. J., Goldstein, A. H., Millet, D. B., Holzinger, R., Kreisberg, N. M., Hering, S. V., White, A. B., Worsnop, D. R., Allan, J. D., and Jimenez, J. L.: Chemical speciation of organic aerosol during the International Consortium for Atmospheric Research on Transport and Transformation 2004: Results from in situ measurements, J. Geophys. Res., 112, D10S26, doi:10.1029/2006jd007601, 2007.

Winklmayr, W., Reischl, G. P., Lindner, A. O., and Berner, A.: A New electromobility spectrometer for the measurement of aerosol size distributions in the size range from 1 to $1000 \mathrm{~nm}$, J. Aerosol Sci., 22, 289-296, 1991.
Wyche, K. P., Blake, R. S., Ellis, A. M., Monks, P. S., Brauers, T., Koppmann, R., and Apel, E. C.: Technical Note: Performance of Chemical Ionization Reaction Time-of-Flight Mass Spectrometry (CIR-TOF-MS) for the measurement of atmospherically significant oxygenated volatile organic compounds, Atmos. Chem. Phys., 7, 609-620, doi:10.5194/acp-7-609-2007, 2007.

Zhang, Q., Alfarra, M. R., Worsnop, D. R., Allan, J. D., Coe, H., Canagaratna, M. R., and Jimenez, J. L.: Deconvolution and Quantification of Hydrocarbon-like and Oxygenated Organic Aerosols Based on Aerosol Mass Spectrometry, Environ. Sci. Technol., 39, 4938-4952, 2005. 